Revista de Estudios Histórico-Jurídicos [Sección Historia de los Dogmas Jurídicos] XXXV (Valparaíso, Chile, 2013) [pp. 587 - 633]

\title{
LA JURISPRUDENCIA ROMANISTA Y LA ORDENACIÓN JERÁRQUICA DE LOS CRITERIOS INTERPRETATIVOS
}

[The Roman Jurisprudence and the Hierarchic Arrangement of the Interpretative Criteria]

\author{
Manuel Jesús Rodríguez Puerto* \\ Universidad de Cádiz, España
}

\section{RESUMEN}

La teoría de la interpretación desarrollada por el ius commune ha sido considerada caótica y peligrosa para la certeza jurídica. Desde este punto de vista, sólo una jerarquía de criterios interpretativos, coronada por el significado literal, es garantía de una aplicación estricta de la norma legal. Sin embargo, la doctrina expuesta por los juristas en tratados escritos en la Baja Edad Media y en el Renacimiento fue más compleja y no defendió el decisionismo arbitrario y ofrecieron listas de criterios interpretativos, que, empero, no jerarquiza rígidamente.

\section{Palabras clave}

Ius commune - Criterios de interpretación - Método.
AbStract

The theory of interpretation developed by ius commune has been deemed to be chaotic and dangerous for the legal certainty. From this standpoint, only one hierarchy of interpretative criteria, crowned by the literal meaning, is guarantee of the strict application of the legal norm. Nonetheless, the doctrine set forth by the jurists in treaties written in the Late Middle Ages and in the Renaissance was more complex and did not defend the arbitrary decisionism and offered lists of interpretative criteria that were not rigidly hierarchized though.

\section{KEYWORDS}

Ius commune - Interpretation criteria - Method.

RECIBIDO el 4 de marzo y ACEPTADO el 24 de agosto de 2013

* Profesor titular de Filosofía del Derecho en la Universidad de Cádiz. Dirección postal: Facultad de Dererecho, Universidad de Cádiz, Avda. de la Universidad s/n, Jerez (Cádiz), España. Correo electrónico: mjesus.rodriguez@uca.es 


\section{INTRODUCCIÓN}

Adam Smith escribió que la libertad de los ciudadanos ingleses estaba garantizada sobre todo por la exigencia de observar rigurosamente la literalidad textual de las leyes y por el escaso poder que tienen los jueces para alterar, extender o corregir su significado ${ }^{1}$. Es difícil resumir mejor la relación entre un método interpretativo estricto y la confianza en las leyes. Desde este punto de vista, sólo una aplicación lo más literal posible permite el cumplimiento real de la ley. Esta defensa del literalismo coincidió con el triunfo del Estado y su monopolización jurídica. El derecho resulta ser una manifestación de la voluntad exclusiva del legislador que se plasma en un texto; cualquier otra realidad diferente a ese texto queda excluida del campo de las fuentes del derecho, y cuando el aplicador (juez o ciudadano) pretendan encontrar la solución jurídica a un problema deberán acudir exclusivamente al texto legal. La respuesta jurídica sólo puede provenir de una aplicación literal del texto, porque introducir principios o criterios exteriores a ese texto supondría acudir a unas apreciaciones ajenas a la voluntad estatal creadora. En consecuencia, el literalismo interpretativo iría unido a la primacía del legislador ${ }^{2}$. Es habitual identificar esta opción metodológica con el Positivismo jurídico, aunque no todas las tendencias y escuelas acogidas bajo esa etiqueta han defendido la adhesión estricta al texto legal ${ }^{3}$. Por otra parte, la tendencia restrictiva de la interpretación había aparecido ya en las monarquías absolutas del siglo XVIII ${ }^{4}$.

Un objetivo principal de las pretensiones estatalistas fue desmontar las doctrinas interpretativas del ius commune, consideradas en buena parte responsables de la situación del derecho propia del Antiguo Régimen. Según este planteamiento, esas doctrinas gracias a la multiplicación de criterios interpretativos, concedían un margen enorme a los juristas a la hora de entender lo prescrito en las leyes;

${ }^{1}$ Cfr. Smith, Adam, Lectures on Jurisprudence (edición de R.L. Meek, D.D. Raphaey P.G. Stein. Oxford, Clarendon Press, 1978), pp. 275 y 283.

${ }^{2}$ Ejemplos de estas actitudes en el Constitucionalismo español del siglo XIX los encontramos en Collantes de TerÁn, María José, La administración de justicia en la época constitucional (Cuenca, Alfonsípolis, 2006), pp. 15, 18, 86-87. En esas páginas aparecen citadas las Lecciones de Derecho Público Constitucional (Madrid, 1821) en las que Ramón Salas defiende de manera rotunda la aplicación literal de la ley sin interpretaciones ni comentarios, porque el juez que abandona la letra de la ley y sigue lo que se llama su espíritu usurpa la función del poder legislativo y actúa contra la libertad individual.

${ }^{3}$ Un positivista de la primera hora como Bentham sí fue favorable al literalismo. Cfr. Bentham, Jeremy, Of Laws in General (edición de H.L.A. Hart, University of London / The Athlone Press, 1970), pp. 232 ss. Ejemplos de actitudes escépticas ante esa posibilidad dentro de la ciencia jurídica alemana del XIX en OGOREK, Regina, Richterkönig oder Subsumtionautomat? Zur Justiztheorie im 19. Jahrhundert (Frankfurt a. M., Klostermann, 1986). En el siglo XX positivistas tan influyentes como Hans Kelsen y H.L.A. Hart han negado la posibilidad de una metodología deductiva para la aplicación de las normas jurídicas.

${ }^{4}$ Véase: GuZmán, Alejandro, Codificación del Derecho civil e interpretación de las leyes (Madrid, Iustel, 2011), pp. 94 ss. 
al final el significado de la ley dependía de la decisión del jurista y desaparecía la certeza jurídica 5 .

Desde luego los juristas del ius commune desarrollaron una interpretación tan alejada del literalismo que llevó al nacimiento de un derecho nuevo sobre la base justinianea. Como ha expuesto Luigi Lombardi, elaboraron un auténtico derecho jurisprudencial, entre otros motivos porque no había un legislador capaz de renovar el añejo derecho romano ${ }^{6}$. El ius commune se insertaba en una concepción más amplia del Derecho, propia de la sociedad jurisdiccional. En ella no existía una fuente única de producción normativa; además, las distintas reglas eran matizadas y reelaboradas según las circunstancias particulares de los intervinientes y sus diferentes estatus. Para esta sociedad, la existencia de leyes únicas para todos aplicadas de manera mecánicamente uniforme era inconcebible ${ }^{7}$. Al formar parte de esa estructura compleja, la interpretatio iuris de los romanistas cargó con una buena porción de responsabilidad en la producción del caos jurídico.

Aun reconociendo que la explicación anterior expone el panorama general, me parece que puede ser interesante un acercamiento a los tratados sobre interpretación redactados por los romanistas de esa época y averiguar si en un plano reflexivo defendieron ese desprecio por la norma general, o si quisieron ofrecer algún tipo de ordenación jerarquizada de los criterios interpretativos. Esto último es un asunto importante. Claus-Wilhelm Canaris recordaba hace unos años que una aplicación de normas garante de la certeza debía respetar una jerarquía

\footnotetext{
${ }^{5}$ Véase por ejemplo: Ajello, Raffaele, Arcana Juris. Diritto e politica nel Settecento Italiano (Napoli, Jovene, 1976), pp. 298 ss. En la p. 312 resalta la importancia de la aplicación cuasi automática de la ley como parte de los ideales ilustrados frente al desorden del ius commune. ClavERO, Bartolomé, La disputa del método en las postrimerías de una sociedad (1789-1808), en Anuario de Historia del Derecho Español, 48 (Madrid, 1978), pp. 331-333, afirma la incompatibilidad de un método axiomático, al que considera constitutivamente liberal, con el ius commune.

${ }^{6}$ Cfr. Lombardi, Luigi, Saggio sul Diritto giurisprudenziale (Milano, Giuffrè, 1975), pp. 164 ss, 182 ss.

${ }^{7}$ Como ha destacado Tau Anzoátegui, Víctor, Casuismo y sistema (Buenos Aires, Instituto de Investigaciones de Historia del Derecho, 1992), pp. 41 y 54 ss., la mentalidad casuista impregnaba aquella sociedad y, por tanto, también la comprensión del derecho. GARRIGA, Carlos, Orden jurídico y poder politico en el Antiguo Régimen, en Istor. Revista de Historia Internacional, 16 (México D.F., 2004), p. 20, señala la relevancia que tiene el jurista a la hora de configurar el derecho en una sociedad de este tipo, frente a lo que ocurre en los órdenes jurídicos legalistas. GonzÁlez Alonso, Benjamín, Jueces, justicia y arbitrio judicial. (Algunas reflexiones sobre la posición de los jueces ante el Derecho en la Castilla moderna), en Vivir el Siglo de Oro. Poder, Cultura e Historia en la época moderna. (Salamanca, Ediciones Universidad de Salamanca, 2003), pp. 228 ss., explica que el juez debía singularizar preceptos, extender, eludir, matizar normas para atender a la diversidad inabarcable de situaciones y posiciones sociales; el arbitrio judicial era imprescindible para conseguirlo. El arbitrio judicial no implicaba siempre irregularidad y capricho, porque se hallaba regulado por la doctrina y el estilo judicial, aunque estas limitaciones estaban abiertas igualmente a interpretación y casuismo. Cfr. Una muestra de los defectos del modelo, referida al derecho castellano, en AlOnso, María Paz, El proceso penal en Castilla (siglos XIII-XVIII). (Salamanca, Ediciones Universidad de Salamanca, 1982), per totum. Una imagen más matizada de ese arbitrio, destacando las restricciones de la actuación judicial en ORTEGO, Pedro, Notas sobre el arbitrio judicial usque ad mortem en el Antiguo Régimen, en Cuadernos de Historia de Derecho, 11 (Madrid, 2004), pp. 230-233.
} 
entre criterios interpretativos para evitar que el resultado quedara en manos del intérprete $^{8}$. Cabe preguntarse hasta que punto la actitud de los romanistas da la razón a Canaris. Es preciso añadir una cautela adicional: no podemos identificar las reflexiones de los romanistas sobre este problema con la práctica interpretativa forense desarrollada en el Antiguo Régimen. Los modos de decidir y de expresar esa decisión a veces resultaban bastante alejados del tipo de argumentación que los historiadores ven expuestas en las teorizaciones de la época; el objeto de este trabajo es precisamente analizar esas teorizaciones?.

\section{UN EXCURSO TEOLÓGICO}

Antes de exponer las ideas de esos juristas puede ser interesante un acercamiento a la explicación sobre la interpretación de las leyes que ofreció Tomás de Aquino. El motivo es la afinidad. Como ha señalado Francisco Carpintero, la filosofía práctica tomista puede ser considerada una exposición de los fundamentos de la mentalidad jurisprudencial romanista ${ }^{10}$.

El problema de la interpretación interesó mucho a los teólogos medievales, pero habitualmente desde planos diferentes del jurídico. El pensamiento griego y más tarde la Patrística se habían preocupado por el significado de los textos. Aristóteles redactó un tratado titulado posteriormente perì hermeneia o de interpretatione según traducción de Boecio en un comentario que se haría muy popular a lo largo de la Edad Media. Pero estos tratados se ocupaban sólo del significado de las oraciones enunciativas, no de las cuestiones propias de la razón práctica, tales como la aplicación de un precepto para determinar el derecho; en este caso, resultaban más útiles la Retórica aristotélica y las reglas proporcionadas por el Derecho romano ${ }^{11}$.

${ }^{8}$ Cfr. Canaris, Claus-Wilhelm, Das Rangverhältnis der klassischen Auslegungskriterien, demonstriert an Standardproblem aus dem Zivilrecht, en BeuthiEN, Volker y otros (editores), Festschrift für Dieter Medicus. Zum 70. Geburtstag (Colonia, Carl Heymanns, 1999), p. 32.

${ }^{9}$ Hay que tener en cuenta las diferencias existentes dentro del mismo derecho común entre la práctica forense y la enseñanza académica, a la que pertenecen los textos aquí estudiados. Véase: Lombardi, L., cit. (n. 6), pp. 122 ss. Igualmente, Ajello, R., cit. (n. 5), p. 55. El desorden era más considerable en la práctica. Aunque defensor de la jurisprudencia romanista tradicional, Alberico Gentili era consciente del desgaste del bartolismo cuando recordaba que el mos italicus no consistía en la mera acumulación de opiniones, sino en la discusión e investigación de causas y razones. Cfr. GenTiLi, Alberico, De iuris interpretibus libri sex (edición de G. Astuti, Turín, Instituto Jurídico de la Universidad, 1937), p. 173. Lo cierto es que la decadencia de la jurisprudencia del ius commune, a causa entre otros motivos, del abuso de autoridades era patente desde el siglo XV. Véase: Carpintero, Francisco, "Mos italicus", "mos Gallicus" y el Humanismo racionalista, en Ius Commune, 10 (Frankfurt a.M., 1978), pp. 120 ss.

${ }^{10}$ Véase: Carpintero, Francisco, Tomás de Aquino ante la ley natural, Dikaiosyne, 8 (Mérida, Venezuela, 2002), p. 26.

${ }^{11}$ Sobre los inicios de la teoría sobre la interpretación como modo de captar el significado de textos en el pensamiento griego y en la patrística, véase: Grondin, Jean, Introducción a la Hermenéutica filosófica (trad. de A. Ackermann. Barcelona, Herder, 1999), pp. 44 ss. Una muestra del interés medieval por estas cuestiones es AQuino, Tomás de, Comentario al libro de Aristóteles sobre la interpretación (trad. de M. Skarica, Pamplona, EUNSA, 1999), "Proemio", p. 9. 
Tomás extrajo los criterios para la interpretación de las leyes sobre todo de Aristóteles, que estableció algunos de los más influyentes en nuestra cultura jurídica ${ }^{12}$. Aconsejaba que las leyes regulasen los asuntos de la manera más pormenorizada posible, porque resultaba más fiable la prudencia del legislador que la del juez individual, más vulnerable a los sentimientos provocados por el caso. Al mismo tiempo reconocía que las leyes no podían determinarlo todo; en ese caso, entra en acción la equidad; es equitativo, según Aristóteles mirar más al legislador que a la ley, y más a la intención y la mentalidad del legislador que al texto ${ }^{13}$. En su Ética a Nicómaco, también afirmaba que toda ley es universal, pero al mismo tiempo admitía la existencia de casos en los que no era posible tratar todas las cosas de modo universal. La ley suele aceptar "lo más corriente" sin ignorar que no lo ha resuelto todo; sin embargo, precisa Aristóteles "el yerro no radica en la ley, ni en el legislador, sino en la naturaleza de la cosa, pues tal es la índole de las cosas prácticas”. Cuando sobrevienen circunstancias no previstas en la ley universal la omisión deberá ser corregida "pues el mismo legislador habría hecho esa corrección si hubiera estado presente y habría legislado así, si lo hubiera conocido" ${ }^{14}$. Se trata de lo que mucho después se llamará idea del legislador racional.

Las reflexiones de Tomás sobre la interpretación de las leyes siguen estas vías aristotélicas y aceptan la tensión existente entre las reglas generales y la determinación de la solución práctica, siempre concreta.

Tomás distingue entre la executio y la interpretatio de la ley. La primera tiene lugar cuando el significado está claro. Ahora bien, ese significado depende tanto de la literalidad de las palabras (verba) como del espíritu (mens) de la ley ${ }^{15}$. Cuando es manifiesto y evidente que el legislador pretendió algo diferente a lo que expresa la literalidad, el juez podrá emplear la intención del legislador, aunque subraya que en tal caso no está realizando una interpretación propiamente dicha (simpliciter), porque el espíritu forma parte del significado, y si el espíritu es claro no hay interpretación ${ }^{16}$.

Cuestión diferente es que la ley justa y de significado claro sea perjudicial en un caso concreto ya que la ley no puede prever todos los casos particulares; en tal

\footnotetext{
${ }^{12}$ Recordemos que el maestro de Tomás, San Alberto Magno, había comentado la Ética a Nicómaco dos veces.

${ }^{13}$ Cfr. Aristóteles, Retórica (trad. de Q. Racionero, Madrid, Gredos, 1990), lib. I, cap. $1^{\circ}$, 1354a-1354b, cap. $13^{\circ}, 1374 \mathrm{a}-1374 \mathrm{~b}$. La presencia de estos criterios en esta obra indica que se trata de argumentos plausibles y contextualizados, no de métodos rigurosos y científicos. Por otra parte, es importante que Aristóteles incluya estos argumentos para solucionar problemas jurídicos en su Retórica, no en el tratado hermenéutico propiamente dicho.

${ }^{14}$ Cfr. Aristóteles, Ética a Nicómaco (trad. de J. Pallí. Madrid, Gredos, 1993), lib. V, 1137b, p. 263.

${ }^{15}$ Esta pareja de conceptos tenía ya una larga historia. Aparecen en la Segunda Epístola de San Pablo a los Corintios, en la que tiene preeminencia el espíritu. Además, San Agustín recoge de San Ambrosio la distinción entre significado literal y espiritual. La influencia de estos planteamientos es imposible de exagerar. Véase: GonzÁLEZ, Gabriel, Dialéctica escolástica y lógica humanista de la Edad Media al Renacimiento (Salamanca, Ediciones Universidad de Salamanca, 1987), p. 194.

${ }^{16}$ Thoma Aquinat., Summa Theologiae, 1a-2ae , q. 96, a. 6, ad secundum (citada según la edición digital de la obra tomista por Enrique Alarcón en http://www.corpusthomisticum.org).
} 
supuesto la ley no debe cumplirse, aunque el incumplimiento debe ser graduado. En primer lugar, si el cumplimiento de la ley según el tenor de sus palabras no produce un peligro inmediato, es mejor remitir el problema al príncipe para que dispense de la obediencia. Según Tomás, la remisión al gobernante es obligada, porque es un problema que afecta a la utilidad de la comunidad y es competencia del gobernante, no de cualquiera que aplique la ley. En cambio, si el peligro es inminente, puede incumplirse la norma, porque la necesidad no está sometida a la ley ${ }^{17}$. Es lícito, porque no se juzga sobre la ley misma, sino sobre un caso individual, en el que no deben ser obedecidas las palabras de la ley ${ }^{18}$. En esta ocasión el problema no lo suscita el entendimiento de las palabras, porque el significado de la ley es claro, sino los resultados injustos a los que lleva una aplicación concreta; por ese motivo la solución de estos casos es tarea de la epiqueya no de la interpretación ${ }^{19}$. Al comentar la Ética a Nicómaco, Tomás explica que la epiqueya ha de intervenir a causa de las insuficiencias inevitables del justo legal, porque toda ley es universal, pero los particulares son infinitos y no pueden ser comprendidos por el intelecto humano, ni regulados en una ley. De algunos asuntos no es posible decir lo verdadero de forma universal, como ocurre en las cosas contingentes; en ellas aunque algo sea verdadero en la mayor parte de los casos, en pocos falla: y tales son los asuntos humanos, para los cuales se dan las leyes ${ }^{20}$. Tomás de Aquino no quiere decir que las leyes, redactadas en forma universal, siempre sean deficientes y su sentido sólo sea cognoscible en el caso concreto. Esto ocurrirá sólo a veces, y entonces el juez deberá recurrir a lo justo equitativo. No obstante, Tomás parece inclinarse por una actitud más hermenéutica (en el sentido actual) cuando indica que la ley es defectuosa en lo particular y esa es la causa de que no todas las cosas puedan determinarse según la ley, porque de las cosas que ocurren raramente es imposible dar ley. Por ese motivo tras la promulgación de la ley es necesaria la sentencia judicial, que aplica el dictamen universal de la ley al negocio particular. La materia de los asuntos humanos es indeterminada y por tanto conviene que su regla, que es la ley, sea también indeterminada y no siempre se entienda del mismo modo ${ }^{21}$. En esta reflexión Tomás nos dice, si lo

\footnotetext{
${ }^{17}$ Thoma Aquinat., Summa Theologiae, 1a-2ae , q. 96, a. 6, resp. Termina afirmando que "si vero sit subitum periculum, non patiens tantam moram ut ad superiorem recurri possit, ipsa necessitas dispensantionem habet anexam: quia necessitas non subditur legi".

${ }^{18}$ Thoma Aquinat., Summa Theologiae, 1a-2 ae, q. 96, a. 6, ad 1: “Ad primum ergo dicendum quod ille qui in casu necessitatis agit praeter verba legis, non iudicat de ipsa lege: sed iudicat de casu singulari, in quo videt verba legis observanda non esse".

${ }^{19}$ Cfr. Thoma Aquinat., Summa Theologiae, cit., 2a-2ae q. 120. No obstante, Tomás matiza añadiendo que también podemos considerar la epiqueya como parte de la justicia legal, si ésta tiene en cuenta tanto las palabras de la ley como la intención del legislador. En cambio, si la justicia legal sólo abarca las palabras de la ley, la epiqueya está fuera de la justicia legal. Summa Theologiae, 2a-2ae q. 121, ad primum. Así pensaba Aristóteles, cfr. Ética a Nicómaco lib. V, 1137b, p. 263.

${ }^{20}$ Cfr. Thoma Aquinat., Sententia libri Ethicorum, lib. 5, lectio 16, 6-7. Consultada en la edición digital ya citada.

${ }^{21}$ Ibídem.
} 
expresamos con una terminología más actual, que la sentencia es la apreciación flexibilizada y contextual de la ley ${ }^{22}$.

A diferencia de la executio (que comprende la epiqueya), la interpretación propiamente dicha sólo entra en acción cuando el significado, que abarca también el espíritu o intención del legislador, no es manifiesto, sino dudoso; en ese caso es necesario trasladar el asunto al gobernante ${ }^{23}$. Puede ocurrir que la intención del legislador sea dudosa, pero no la literalidad de los términos legales; entonces Tomás exige al juez que decida según el significado literal (que sí está claro) o consulte al superior ${ }^{24}$.

Está claro que para Tomás la competencia del juez abarca sólo la flexibilización de las palabras en función de la finalidad de la ley, que es su verdadero significado; en ningún caso puede crear un significado nuevo ${ }^{25}$. Observemos que Tomás no remite la solución del problema jurídico exclusivamente a las peculiaridades del caso. Pretende indicar que esa solución no debe proceder del arbitrio del aplicador, sino que ha de basarse en las directrices establecidas en la ley. Otra cosa es que éstas no se apliquen de manera mecánica, porque los asuntos prácticos (y el derecho forma parte de ellos) son competencia de la prudencia, refractaria a modos de pensar exactos.

Es curioso que no mencione la prudentia iuris entre las diferentes partes subjetivas de esta virtud. Entre ellas está la rectora de multitudes, dividida según la especie de actividades a la que se dirige: bien negocios especiales, bien generales, que son los propios de la prudencia económica y de la política; esta segunda se refiere al bien común y por tanto afecta a la justicia legal ${ }^{26}$. Sin embargo, queda claro que para Tomás determinar el comportamiento adecuado a la ley es tarea de la prudencia, porque puede ser objeto de consilium y éste sólo se da para asesorar

${ }^{22}$ Con carácter general, Tomás entiende que la razón práctica parte de preceptos generales para llegar a conclusiones concretas, pero éstas no pueden gozar de la infalibilidad propia de las conclusiones demostrativas de la ciencia a causa de la contingencia de la realidad humana. Y subraya: cuanto más se desciende en la concreción tanto más aparecen los defectos del precepto general. Cfr. Summa Theologiae, 1a-2 $2^{\text {ae }}$, q. 91, a. 3, ad tertium; q. 94, 1-2, a. 4, resp; q. 96, a. 4 , resp. Cabe preguntar, no obstante, hasta qué punto este planteamiento de Tomás alcanza la aplicación de las leyes humanas. Porque los ejemplos que aduce suelen referirse a las relaciones entre principios de la ley natural y su plasmación en reglas de origen humano, más que en los problemas generados por la determinación judicial de lo justo (el ius). Con independencia de esa cuestión, Tomás es consciente de la complejidad de los asuntos humanos y de la dificultad de normarlo todo desde unas normas supremas, pero al tiempo reconoce la posibilidad de establecer reglas que permitan resolver razonablemente las cuestiones jurídicas habituales sin necesidad de inventar la solución para cada caso, porque éste no siempre es único e irrepetible.

${ }^{23}$ Cfr. Thoma Aquinat., Summa Theologiae, cit., 2a-2ae, q. 120, a. 1, ad tertium.

${ }^{24}$ Thoma AquinAt., Summa Theologiae 1a-2ae q. 96, a. 6, ad 2: "Ad secundum dicendum quod ille qui sequitur intentionem legislatoris, non interpretatus legem simpliciter; sed in casu in quo manifestum est per evidentiam nocumenti, legislatore, aliud intendisse. Si enim dubium sit, debet vel secundum verba legis agere, vel superiores consulere".

${ }^{25}$ Tomás exige juzgar según leyes y no dejar la solución de los juicios sólo al arbitrio de los jueces. Véase: Summa Theologiae, $1^{\mathrm{a}}-2^{\mathrm{ae}}$, q. 95, a. 1, ad sec.

${ }^{26}$ Thoma Aquinat., Summa Theologiae 2a-2ae, q. 48, a. único, resp.; 2-2, q. 47, a. 10, ad primum. 
en aquello que debemos hacer. En efecto, en estas acciones no sirven las reglas de la técnica, que predeterminan la solución, sino la recta razón de la prudencia que requiere a veces del consejo. Subraya que cabe pedir consejo sobre lo estatuido en la ley y de ahí el nombre de jurisconsulto, y aclara que en ese supuesto el consejo no es solicitado para elaborar la ley, sino para averiguar la acción correcta según la norma. Y es que la ley es directiva para el comportamiento de quien pide el consejo: es razón para poner algo en práctica (aliquid operandi) ${ }^{27}$. Ese poner algo en práctica es, claro está, objeto de la virtud de la prudencia.

Por supuesto, el que la prudencia no esté sujeta a métodos estrictos, no implica que la determinación del derecho (y dentro de esa actividad la interpretación de la ley) dependa exclusivamente de consideraciones circunstanciales, prescindiendo de las prescripciones generales según el parecer del prudente. Porque la prudencia desvela la acción moralmente exigible y en bastantes circunstancias lo correcto es seguir lo prescrito en las palabras de la ley entendidas literalmente. Ocurre, sin embargo, que a veces no es así y no hay técnicas precisas que nos indiquen con carácter previo como establecerlo con completa certidumbre: por eso es tarea de la prudencia y no del ars. Está claro para Santo Tomás que la determinación del significado de la ley no puede estar sujeta a un uso rigurosamente jerarquizado, porque en ocasiones imprevisibles depende de reflexiones abiertas a lo circunstancial. La prevalencia del espíritu de la ley, sujeta a las apreciaciones prudenciales, es muestra de la imposibilidad de esa jerarquía.

Que la prudencia no es casuismo radical lo subraya Tomás cuando escribe que los singulares infinitos de los que se ocupa la prudencia pueden reducirse por experiencia a algunas nociones finitas que recogen los que ocurre con frecuencia y el conocimiento de esto último es suficiente para la prudencia humana ${ }^{28}$. Las leyes humanas desempeñan ese papel en las relaciones de justicia y no deben ser consideradas un material maleable.

Por otra parte, la vinculación a la ley que él defiende no supone el sometimiento del juez a una voluntad irracional, ya que ésta nunca produce una auténtica ley, sino su versión corrupta. Como ha destacado Francisco Carpintero, Tomás no concibe el orden moral -y para este teólogo el derecho y la justicia están integrados en él- como un conjunto de órdenes e imperativos, sino más bien como una serie de fines y bienes humanos dignos de cumplimiento. Consecuentemente, las leyes no están basadas en el mero imperativismo de una voluntad superior, sino en un imperativo basado en la razón que tiene en cuenta esos bienes humanos ${ }^{29}$. Desde estas premisas debemos entender que la vinculación del intérprete a la ley consiste en tener en cuenta esos fines en el momento de determinar el derecho. Esta consideración prudencial de lo jurídico no le hace olvidar la importancia de autoridad en el momento de la interpretación. El juicio implica compulsión y la presencia de una autoridad pública; según Tomás, es la misma autoridad de la

${ }^{27}$ Thoma Aquinat., Summa Theologiae, 1a-2ae, q. 14, a. 3, ad sec.

${ }^{28}$ Thoma Aquinat., Summa Theologiae, 2a-2ae, q. 47, a. 3, ad sec.

${ }^{29}$ Véase: CARPIntero, Francisco, Justicia y ley natural: Tomás de Aquino y los otros Escolásticos (Madrid, Servicio de Publicaciones de la Facultad de Derecho de la Universidad Complutense, 2004), pp. 50-51 y 90 , entre otras. 
que dimanan el poder para legislar y para interpretar ${ }^{30}$. Recordemos que la ley es manifestación del poder político y no afirmación de cualquier particular, de forma que el establecimiento de los criterios para el derecho debe estar centrado en la instancia política, que además Tomás prefiere tendente a la unidad si tenemos en cuenta la simpatía por la fórmula monárquica ${ }^{31}$.

\section{La TRADICIÓN DEL DERECHO COMÚN EN MATERIA}

\section{DE INTERPRETACIÓN DE LAS LEYES}

A pesar de la importancia que concedían a la labor interpretativa, estos juristas tardaron en redactar tratados específicamente destinados a exponer el modo en el que la entendían: no eran muy aficionados a teorizar sobre su trabajo. Desde luego, el concepto de interpretación aparece de forma fragmentaria a lo largo de glosas y comentarios al hilo de la resolución de problemas concretos, pero sólo en fecha tardía algunos romanistas se preocuparon por explicitar de manera compendiosa sus doctrinas sobre la interpretación jurídica.

Los primeros tratados estuvieron dedicados a cuestiones parciales, como la extensión del significado de la ley. Es el caso de los redactados por Mateo Mattesilano o Bartolomeo Caepolla, aparecidos entre 1460-1475 y seguidos por el de Petrus Andreas Gammarus unos cincuenta años después. El primer tratado completo sobre interpretación es el de Constantino Rogerio, titulado De iuris interpretatione (1463). Algo posterior, de 1496, es el elaborado por Stefano de Federici y titulado De legis interpretatione ${ }^{32}$. No contienen ideas originales, pero precisamente ahí radica buena parte de su valor: muestran las concepciones compartidas por los romanistas durante los siglos bajomedievales ${ }^{33}$. Por ese motivo, la mayor parte de los criterios interpretativos que ofrecen estos juristas proceden de esa tradición ya consolidada.

Además de preocuparse por la interpretación extensiva, Bartolomeo Caepolla también escribió un Comentario sobre el título De verborum significatione de los Digesta $^{34}$. En él dedica varias páginas a explicar qué es la interpretación. Una de

${ }^{30}$ Thoma Aquinat., Summa Theologiae, 2a-2 $2^{\mathrm{ae}}$, q. 60, a. 6, resp.

${ }^{31}$ Thoma Aquinat., De regno ad regem Cypri, lib. I, cap. $3^{\circ}$, de la edición digital cit.

${ }^{32}$ Sobre la aparición sucesiva de estos tratados, véase: PIANO-MORTARI, Vincenzo, Ricerche sulla teoria dell'interpretazione del diritto nel secolo XVI, I: La premesse (Milano, Giuffrè 1956), pp. 7 ss. SCHRÖDER, Jan, Recht als Wissenschaft (München, Beck, 2001), pp. 51-52; MaCLEAN, Ian, Interpretation and Meaning in the Renaissance. The Case of Law (Cambridge University Press, 1992), pp. 84-85; GuZmán, A., Codificación, cit. (n. 4), p. 38. Tanto Piano como Schröder destacan que el de Rogerio es el primer tratado dedicado a la interpretación jurídica en general. Además, las fuentes mencionan obras sobre interpretación de Lucas da Penna y de Rainiero de Forlivio, pero no se conservan. Cfr. Lange, Hermann - Kriechbaum, Maximiliane, Römisches Recht im Mittelalter, II: Die Kommentatoren (München, Beck, 2007), p. 350.

${ }^{33}$ Destaca esta característica PIANO MORTARI, Vincenzo, Il problema dell" interpretatio iuris" nei Commentatori, en Annali di Storia del Diritto, 2 (Milano, 1958), pp. 105-106.

${ }^{34}$ Caepolla era un hombre de formación más extensa que la estrictamente jurídica. Conocía obras de la Antigüedad, la patrística, la filosofía contemporánea, pero sus escritos sobre derecho lo muestran fiel a la tradición bartolista. Cfr. Lange, H. - Kriechbaum, M., Die Kommentatoren, cit. (n. 32), p. 844 . 
las cuestiones planteadas era la diferencia entre significado e interpretación, que había preocupado siempre a estos juristas. Escribe que la significación consiste en el verdadero y propio entendimiento de la palabra, mientras que la interpretación es la extensión o limitación de esa intelección del significado ${ }^{35}$. Esta distinción no implica que el significado fuera una realidad dada de manera inmediata al jurista. Caepolla comenta una serie de argumentos e instrumentos necesarios para conocer el significado propio de las palabras: la definición de las palabras, el significado que da la misma ley, la adecuación a la materia tratada, la proporcionada por la comprensión común, la autoridad de los prudentes, el que quiso dar el creador de la palabra o el legislador, etc. ${ }^{36}$. Es preciso tener en cuenta, aclara Caepolla, que la inteligencia de las palabras en el derecho coincide con el espíritu, razón o sentido de la ley. Además, ha de coincidir con el derecho común. No obstante, si hay dudas, las palabras deben entenderse según suenan. También añade que debe escogerse el significado más favorable, la que sea más sana (de forma que la sentencia se adapte al negocio y éste a la sentencia), la más eficaz, la más útil, razonable, adecuada al uso común ${ }^{37}$.

La interpretación aparece cuando el caso controvertido no está contenido en las palabras ni en el espíritu de la ley, pero posee una identidad de razón con lo recogido en la ley, de forma que puede practicarse la extensión de ésta al caso ${ }^{38}$. Nos advierte de que el asunto no es pacífico: en la Glossa se dice que la comprensión de la ley según su espíritu es interpretación, pero Angelo Aretino y Baldo critican esa opinión; este último lo justifica afirmando que el espíritu de la ley es la misma ley, no una interpretación. Caepolla añade varias acepciones de interpretación que contribuyen al aumento de la complejidad ${ }^{39}$. A veces podemos entenderla como el significado abierto y claro de las palabras, aunque también es el significado claro según su espíritu; también es la declaración de la voluntad escondida. Otras veces equivale a traducción o a la exposición de la verdadera intelección de las palabras. E incluso algunos hablan de la interpretación declarativa junto a la extensiva, la restrictiva y la correctiva. Aunque él acepta al final que la interpretación sólo tiene lugar cuando hay ambigüedad ${ }^{40}$.

En realidad, la distinción entre significado e interpretación quizá no sea tan

${ }^{35}$ CAEPOlla, Bartolomeo, In titulum de verborum et rerum significatione doctissima commentaria. (Lyon, 1551), col. 25, 109: "Quaero tercio, in quo differat significatio et interpretatione? Dic quod significatio est, quando non receditur a vero et proprio intellectu vocabuli, sed quando dilatatur, seu extenditur, vel coarctatur seu restringitur intellectus vocabuli: tunc ista non dicitur significatio, sed interpretatio". Esta diferencia era habitual entre estos juristas. Al respecto: GuZmán, A., Codificación, cit. (n. 4), p. 63. SCHÖdER, J., Recht als Wissenschaft, cit. (n. 32), pp. 54 ss., señala que desde la Edad Media hasta el siglo XVIII el concepto de interpretación es impreciso: puede abarcar la búsqueda del significado, la extensión o restricción, la corrección, etc., según los autores.

${ }^{36}$ Caepolla, B., In titulum, cit. (n. 35), col. 26, 112.

${ }^{37}$ Ibíd., col. 27 ss., 116 ss. Sobre la relevancia de la costumbre para seguir una interpretación cfr. también col. 41, 149.

${ }^{38}$ Ibíd., col. 34, 131 ss.

${ }^{39}$ Ibíd., col. 34-35, 131-133.

${ }^{40}$ Ibíd., col. 35 ss, 135 ss., col. 37,140. 
relevante. Caepolla escribe que tanto la significación como la interpretación se refieren a la comprensión de las palabras ${ }^{41}$. Y en ambas es precisa la argumentación para llegar a una solución.

Esta abundancia de criterios muestra la complejidad del problema interpretativo en el ius commune. Caepolla la acepta y no muestra ningún procedimiento fijo para solucionarla: enumera una serie de criterios y principios, a veces contradictorios, que podrán ser empleados por el jurista en función del asunto que tenga entre manos. Lo más destacable es la referencia al significado de las palabras y al espíritu de la ley. Desde los mismos inicios del ius commune la relación verbamens fue el núcleo de los problemas interpretativos ${ }^{42}$. Y ya hemos visto, al tratar la interpretación de las leyes en Santo Tomás, que gozaban de acogida amplia en la cultura cristiana desde sus inicios ${ }^{43}$. Pero, como es habitual, la realidad comprendida en esta pareja de conceptos no es simple. Alejandro Guzmán explica que los romanistas emplearon dos conceptos básicos, sensus y verba; el primero abarcaba la mens, la sententia, el intellectus, la causa o la ratio legis; las verba aparecían también como littera o scriptura ${ }^{44}$. Esta pluralidad de facetas aumentó la dificultad de la doctrina interpretativa.

La obra de Constantino Rogerio sigue los carriles establecidos por Caepolla. Como él, se preocupa por establecer los delimitar el campo de la interpretación. Afirma que el asunto es polémico. Según autores como Bartolo, Baldo y Dyno la interpretación sólo aparece cuando hay una extensión o restricción del significado. Pero según la Glosa la interpretación en sentido propio es la significación abierta (clara) de la palabra; la restricción o ampliación sólo es interpretación en sentido amplio $^{45}$. Él prefiere la primera acepción.

En consecuencia, es preciso comenzar estableciendo qué es el significado. Según Rogerio, es el propio y verdadero sensus atribuido a una afirmación por el intelecto, o lo estatuido por el legislador; además, el significado a veces surge de las palabras usadas, otras de las cosas significadas ${ }^{46}$.

Rogerio expone diferentes elementos desde los que extraer el significado

${ }^{41}$ Ibíd., col. 27, 114 ss.

${ }^{42}$ Véase: CORTESE, Ennio, La norma giuridica (Milano, Giuffrè, 1962), I, pp. 286 ss.; también: Piano Mortari, V., Il problema dell" interpretatio iuris", cit. (n. 32), p. 47; LANGe, H. - Kriechbaum, M., Die Kommentaroren, cit. (n. 32), pp. 340-341, 346-348.

${ }^{43}$ Caepolla cita a veces a autores de tradición retórica, aunque de manera escasa comparada con la mención de textos jurídicos.

${ }^{44}$ Véase: GuZmán, A., Codificación, cit. (n. 4), p. 46.

${ }^{45}$ Rogerio, Constantino, De iuris interpretatione, en Tractatus Universi Iuris (Venecia, 1584), I, p. 387: “Aliqua est declarativa [la interpretación], de qua dixi in eodem tractatu in titulo de declaratoria expositione. Et dico, quod ultima proprie non est interpretatio secundum Baldum in dicta rubrica de verborum significatione, quia tantum intepretatio dicitur quando fit extensio, vel restrictio. Sed attende, quia glossa in dicta l. prima de origine iuris dicit totum oppositum: dicens quod interpretatio proprie denotat vocabuli apertam significationem: sed large ponitur pro arctatione, vel restrictione".

${ }^{46}$ Ibíd., "Secundo principaliter quaero, quid sit interpretatio? Pro cuius declaratione primo videamus quid sit significatio. Et significatio est propius, et verus sensus attributus dictioni ab intellectu, vel statuto legislatoris. [...]. Et subiicit quod significatio quandoque sumitur a verbo disponente, quandoque a re disposita; et hinc intitulatur ibi de verborum et rerum significatione". 
propio. Lo problemas surgen cuando aparecen palabras generales indefinidas o palabras que admiten diferentes significaciones propias; en tales supuestos es preciso elegir un significado. El punto de partida es que las palabras y el espíritu de la ley conforman el significado y no es lícito apartarse de estos dos criterios cuando aparecen con claridad. No podemos desviarnos de las palabras y su propiedad (que como hemos visto es concebida de manera relativamente amplia) por un "favor particular", porque sobre aquello que consta en la significación de la palabra no hay lugar para la interpretación. Subraya que si no es lícito que nos apartemos de las palabras de la ley, menos aún lo es ignorar su espíritu, porque ésta se obtiene desde la razón; esta mens o ratio es "más potente que las palabras", porque la intención no sirve a las palabras, sino al revés. No nos preocupamos de las palabras, si el ius, la razón natural o la mens, que constan claramente, muestran otro significado ${ }^{47}$. En otro momento explica que la ratio o mens es el alma y médula de la ley y las palabras su superficie; la ratio debe ser ponderada siempre si se quiere entender perfectamente la ley; si se atiende siempre al sentido de las palabras, postergando el espíritu, se pierde el sentido de la verdad. Pues el espíritu siempre es más potente que las palabras. Y así no decimos que la intención debe servir a las palabras, sino las palabras a la intención y al espíritu ${ }^{48}$. Por este motivo, podemos considerar que el significado de la ley está sobre todo en su espíritu; en él aparecen contenidos que no están expresados en las palabras por lo que su aplicación a un caso no es extensión, es decir, no es interpretación, sino simplemente aplicación de la ley ${ }^{49}$. Y es que la razón de la ley es la ley misma ${ }^{50}$.

${ }^{47}$ Ibíd., p. 390 dorso, 12-14: "Quia certum est, quod non possumus recedere a verbis, seu ipsorum proprietate, propter aliquem favorem: quia ex eo constat de significatione vocabuli, non est locus interpretationi. [...]. Si ergo nullatenus licitum est recedere a verbis, ubi de forum significatione constat, multo minus licebit recedere a mente, de qua constat: quae mens, ut iam plures dixi excerpitur ex ratione. Et probo consequentiam, quia ista mens seu ratio est potentior quam verba, quia non intentio verbis, sed verba intentioni debent deservire, $c$. in his extra de verb. signific. et de verbis non curamos, ubi ius, vel ratio naturalis, vel mens, de qua constat, aliter sonant".

${ }^{48}$ Ibíd., p. 386 dorso, 17-20: "Dic. de qua supra dixi, quod lex debet esse rationabilis: ista ratio legis nibil aliud est, quam mens legis. [...] Et ista mens legis et anima legis, ut notatur in 1. cum mulier viri lenocinio, Digestum, soluto matrimonio. Et istam rationem, seu mentem legis semper ponderabis, si vis perfecte intelligere leges: quia alias, si verba simpliciter sectaberis, postergata mente, sensum veritatis perdes. Nam, ut dicit text. In co, praeterea de verborum significatione plerunque dum proprietatem verborum attendimus, sensum veritatis amittimus. Nam semper mens est potentior, quam sint verba. Hinc dicimus quod non intentio verbis, sed verba intentioni, et menti debent deserviri".

${ }^{49}$ Ibíd., p. 386, 27-28: "Ergo quod ex ratione, seu mente percipitur, dicitur inmediate ex lege procedere, et consequenter non sit extensio. Probo etiam, quia 1 . Praetor ait in $\$ 1$, Digestum de operis novi nunciacione dicit, edicto expressum est, et tamen in edicto illud, de quo ibi, non erat expressum quantum ad verba, sed solum quantum ad mentem, $u$ tibi per glossam et Doctores. Ecce ergo ibi cassum, quod id, quod ex mente legis percipitur, dicitur esse expressum in lege".

${ }^{50}$ Rogerio, C., cit. (n. 45), p. 388 dorso, 11, explica que, según algunos, la sentencia contra la ratio legis no es contraria al derecho expreso, pero prefiere la opinión contraria que encuentra en el Abad Panormitano y en Antonio Butrio: "quia ratio legis est ipsa lex. Et hoc credo verius, per ea, quae dixi in prima parte huius Tractatus: ibi habuistis iura, glossas, et auctoritates ad hoc". Por tanto, el derecho expreso no es lo meramente literal, sino también la ratio legis. Observemos 
Pero, aunque Rogerio no lo reconozca expresamente, sí defiende que la obtención del significado propio requiere argumentar.

Como indicaba más arriba, la mens legis es una noción un tanto amplia. No se identificaba sin más con la ratio legis. Alejandro Guzmán señala al respecto que los romanistas medievales solían utilizar de manera indistinta las expresiones causa legis, mens legis, sententia legis o ratio legis para nombrar la causa final de la ley, o dicho de otra forma, las razones del legislador para establecerla ${ }^{51}$. Según Jan Schröder, no es fácil decir qué significa mens legis en el ius commune. Puede ser razón, causa, finalidad, fundamento de la ley. En cualquier caso indica que la ley no ha de ser una mera regla de contenido azaroso, sino que tiene una base racional $^{52}$.

Según explica Rogerio, el espíritu también acoge las consecuencias que necesariamente se derivan de las palabras de la ley: esto no es una interpretación extensiva, sino el significado recogido en la misma ley (en su espíritu $)^{53}$. Expresado de otra forma, la palabra de la ley va más allá de una literalidad estricta. Otras veces, la mens legis habrá de colegirse desde la intentio legislatoris, que es concebida también en términos amplios, como razón de la ley y no como la voluntad psicológica subjetiva del legislador.

En resumen, Rogerio denomina verba lo que los juristas actuales denominan significado literal; la mens expresa en cambio un significado que podríamos denominar hoy "finalista" o teleológico, erigido a partir de la finalidad o razón que fundamenta la ley; este parece ser, para Rogerio, el significado auténtico de la norma y su elucidación no es interpretación si resulta claro a partir de los criterios que he reseñado.

Esta distinción habitual en el ius commune ha generado algunos problemas de comprensión a los historiadores. Como señala Clausdieter Schott, hasta fines del siglo XVIII era opinión común entre los juristas que no hay interpretación si las palabras son claras ("interpretatio cessat in claris"). Sin embargo, Schott considera engañoso el principio, porque su aplicación requiere que previamente debamos determinar si el texto es claro u obscuro. Muchos de estos juristas -Schott cita al mismo Rogerio, entre otros- pensaban que la interpretación declarativa, en la que se establecía la coincidencia entre verba y mens, no era verdadera interpretación. Incurrían así en una cierta petición de principio: para saber si el significado es claro es preciso saber antes lo que dice el espíritu de la ley y eso implica ya interpretación (tal y como reconocen las teorías actuales sobre interpretación) ${ }^{54}$. La

que de pasada aparecen aquí las fuentes de la argumentación típicas del romanista: el texto normativo, la Glosa y los autores investidos de autoridad.

${ }^{51}$ GuZmán, Alejandro, Ratio scripta (Frankfurt a.M., Vittorio Klostermann, 1981), p. 21. Cortese, E., La norma, cit. (n. 42), II, p. 296, explica que los juristas solían identificar los verba legis con la voluntad de legislador, y la mens legis con la equidad o razones justificativas contenidas en la ley.

${ }^{52}$ Véase: Schröder, J., Recht als Wissenschaft, cit. (n. 32), p. 60.

${ }^{53} \mathrm{Al}$ preguntarse si las leyes correctivas pueden ser objeto de ampliación según su espíritu, explica que sí "quo aut ista mens percipitur non ex ratione, sed ex necessaria consequentia verborum expressorum, et tunc dico quod illum casum aplectitutr lex [...]".

${ }^{54}$ Véase: ScHOTT, Clausdieter, "Interpretatio cessat in claris". Auslegungsfähigkeit und 
posible confusión se desvanece si tenemos en cuenta la advertencia de Alejandro Guzmán: cuando los juristas escriben que "in claris non fit interpretatio" emplean la palabra interpretación en la acepción específica de extensión del significado de la ley y no en la acepción de significado propio $^{55}$. En consecuencia, este brocardo no excluye que la determinación del significado claro de la ley (que se basa en la literalidad y el espíritu de las palabras) requiera el empleo de alguna argumentación, tal y como enseñan Caepolla, Rogerio y tantos civilistas.

Al tratar de la interpretación en sentido estricto (es decir, la que va más allá del significado propio cognoscible según los criterios mencionados en los párrafos anteriores), Rogerio se interesa por el orden que debe seguirse en esa tarea. Antes de emplear los diferentes criterios, es preciso considerar prólogos e introducciones de la ley para establecer de qué tipo de norma se trata (correctiva, odiosa, favorable, etc.), porque de ahí se derivan márgenes de interpretación diferentes ${ }^{56}$. En efecto, las leyes que corrigen normas penales anteriores aminorando penas han de interpretarse de manera amplia. Pero, en general, las leyes penales no pueden ser objeto de interpretación extensiva, al menos la parte no favorable de la ley, es decir, la pena ${ }^{57}$. Es preciso aclarar que Rogerio se refiere aquí a normas que van más allá de lo que hoy denominamos derecho penal, porque abarca todas las que establecen sanciones, nulidades, etc. propias del lo que hoy llamamos derecho civil. Por otra parte, las leyes que se apartan de las reglas generales (porque establecen excepciones, privilegios, correcciones al ius commune) no pueden ser objeto de extensio, pero sí de interpretación restrictiva.

Una vez establecido el tipo al que pertenece, es necesario averiguar si la ley en cuestión ha sido interpretada por la costumbre en un modo determinado; si eso ocurre, debe adoptarse esa interpretación, aunque sea contraria a la communis sentencia. Tras este criterio, debe ser considerada "diligentemente" la mens de esa ley, que se deriva desde la razón. Y seguidamente hay que atender a las palabras. Rogerio alega que este orden ha sido establecido por los doctores, entre los que destaca Bartolo ${ }^{58}$. Se establece así una jerarquía expresa en la que parece prevalecer la interpretación usual.

Auslegungsbedürftigkeit in der juristischen Hermeneutik, en SCHRÖDER, Jan (editor), Theorie der Interpretation von Humanimus bis zur Romantik. Rechtswissenschaft, Philosophie, Theologie (Stuttgart, Steiner, 2001), pp. 157, 174, 176, 180-181. En una línea similar, MACLEAN, I., cit. (n. 32), pp. 89-90n recuerda que la Hermenéutica actual rechaza la existencia de un grado cero de significado, mientras que los juristas medievales afirmaban que no hay interpretación si las palabras son claras; sin embargo, MacLean añade que esa afirmación medieval no es tan rotunda, porque la claridad ha de ser establecida mediante otros criterios de manera que la calificación de "claro" tiene un carácter más bien retórico para ocultar otras cuestiones.

${ }^{55}$ Véase: GuZmán, A., Codificación, cit. (n. 4), pp. 62 ss.

${ }^{56}$ Rogerio, C., cit. (n. 45), p. 387 dorso: "Quarto principaliter quaero de ordine servando interpretatione Iuris. Super quo dic, quod primo ante, et ante omnia iuris interpres loco introductionis, et isagoges, debet considerare, qualis sit lex, videlicet, an correctiva, exorbitans, odiosa, vel favorabilis, aut neutralis".

${ }^{57}$ Ibíd., p. 388 dorso, 391, dorso.

${ }^{58}$ Ibíd., "Quia primo prospicere debet, an illa lex de cuius interpretatione agitat, fuerit per consuetudinem certo modo interpretata, prout fuit lex dos a patre, Codex soluto matrimonio, quae per consuetudinem fuit interpretata secundum opinionem Martini, licet communis sentencia sit ad 
A pesar de su aparente sencillez, esta ordenación no está exenta de problemas. Uno de ellos es la relación entre la consuetudo loquendi y la mens de la ley. Según Rogerio, que adopta la actitud acostumbrada entre los juristas del ius commune, es preciso distinguir dos posibilidades. Si la consuetudo interpreta la ley entera, se debe seguir la interpretación dispuesta en esa costumbre. En cambio, si lo interpretado es una palabra de la ley, y hay conflicto entre la costumbre y la ratio legis prevalece ésta, que expresa el significado propio de la palabra según el espíritu de la ley59. A partir de estas precisiones la jerarquía de criterios interpretativos adopta un orden inverso al inicial. En principio el jurista podrá atenerse a lo que podríamos llamar interpretación usual, a menos que ésta contravenga el significado claro de los términos legales; pero los términos legales no serán la guía más segura si a su vez no concuerdan con la razón del precepto ${ }^{60}$. Parece, entonces, que esta última es la clave de la tarea interpretativa.

Esta exigencia de valoraciones materiales abre nuevos frentes que limitan aún más la posibilidad de una organización meramente técnica de la interpretación. $\mathrm{Al}$ desempeñar ese papel tan relevante la ratio, el jurista se ve obligado a realizar consideraciones que no pueden ser resueltas mediante la técnica. Ocurre de manera destacada cuando Rogerio menciona la necesidad de tener en cuenta el bien de la respublica: para favorecerlo es lícito apartarse de la locutio generalis ${ }^{61}$.

Es llamativo que Rogerio concluya con la recomendación de tener presentes las advertencias de Cicerón en su tratado De oratore: muchos hombres juzgan con odio, amor, etc., más que con la verdad, las normas del derecho, las leyes o las formas del juicio ${ }^{62}$. Parece claro que este jurista considera necesario juzgar mediante textos legales y procedimientos establecidos para evitar que la pasión y el arbitrio enturbien la decisión jurídica. Y es que a pesar de la complejidad que posee la obtención de su significado, Rogerio sostiene que mediante la interpretación no puede ser corregida la ley ${ }^{63}$.

oppositum, et tunc dico standum esse illi consuetudini interpretanti. [...]. Secundo debet considerare diligenter mentem ipsius legis, quae ex ratione excerpitur. [...]. Tertio debet considerare verba. Et istum ordinem interpretandi ponunt Doctores, maxime Bartolus in lex non possunt, ff de legibus. Ex quo ordinis colligis, consuetudinem vincere mentem, seu rationem, et mentem vincere verba [...]". El usus loquendi como criterio interpretativo procedía de la tradición retórica y estaba bastante difundido en la época.

${ }^{59}$ Ibíd., p. 388: "Et tunc sine dubio non recedam ab eius proprietate propter consuetudo loquendi: quia tunc constat de mente legis, quod voluit intelligere secundum proprietatem vocabuli, ut eius ratio demonstrat, no autem secundum consuetudine loquendi".

${ }^{60}$ Comentando la jurisprudencia romanista, Guzmán, A., Codificación, cit. (n. 4), p. 53, explica que el recurso a la ratio legis ha de hacerse cuando consta auténtica y fehacientemente para evitar la manipulación del texto normativo.

${ }^{61}$ Rogerio, C., cit. (n. 45), p. 391 dorso, 6: "Dico quod ubicumque constitutio tendit ad favorem reipublicae, et amplificanda in tantum, ut pro amplificando reipublicae favorem licitum sit recedere a generali locutione".

${ }^{62}$ Ibíd., pp. 394, 30: "Adde etiam verba singularia Ciceronis in lib. 2 de Oratore, in quintis, quod multo plura homines iudicant odio, aut amore, aut cupiditate, aut iracundia, aut dolore, aut laetitia, aut spe, aut timore, aut terrore, aut aliqua promocione mentis, quam veritatem, aut iuris norma, aut iudicii forma, aut legibus".

${ }^{63}$ Ibíd., p. 392, dorso. 
Como indiqué más arriba, el tratado de Rogerio carece de originalidad. Esta línea tradicional aparece también en otro tratado algo posterior y bastante más completo redactado por Stefano de Federicis. En el prefacio deja clara su intención. Afirma que la justicia es la virtud fundamental para la convivencia, y que las leyes son imprescindibles para su mantenimiento; para conseguirlo es preciso que la interpretación de las leyes esté bien ordenada, algo que hasta ahora no existe a juzgar por la abundancia de tratados y la diversidad de opiniones que acaba confundiendo todo ${ }^{64}$. Esta introducción es interesante, porque muestra la relevancia que estos juristas concedían a la ley como norma general reguladora de los asuntos públicos, y al mismo tiempo es una prueba de que los romanistas de la época no estaban orgullosos del casuismo enojoso en que había derivado la jurisprudencia. Federicis confiesa que ese es el motivo que le lleva a redactar su tratado. Estudiar los criterios interpretativos es imprescindible, porque interpretar las leyes sin el conocimiento de estos lugares tópicos es igual a viajar por mar sin barco, cortar madera sin un hacha, andar sin pies, volar sin alas o navegar sin conocer el mar ni sus rutas ${ }^{65}$. La referencia a los lugares y a los tópicos es interesante. Influidos por el Humanismo, algunos romanistas se esforzaron en redactar compendios a partir de loci comunes o topoi propios de la retórica humanista con la finalidad de facilitar la enseñanza y el trabajo de los juristas ${ }^{66}$. Sin embargo, Federicis no sigue en esta obra los carriles humanistas, sino que expone la práctica interpretativa tradicional de los juristas del ius commune. De todas formas, la referencia a los tópicos es relevante para valorar su tratado. Encontramos en él la descripción de una serie de criterios relacionados con los diferentes aspectos del problema interpretativo y a disposición de jurista según se presenten las peculiaridades del problema. Esta es precisamente la característica principal del razonamiento tópico, con independencia de la adscripción a la vertiente renacentista: la diversidad de puntos de vista relevantes acerca de un problema ${ }^{67}$.

$\mathrm{Al}$ comenzar, Federicis se preocupa por discernir las diferentes cuestiones de las que tratan los juicios: la determinación de los hechos (quaestio coniecturalis); la definición, es decir la calificación jurídica de lo controvertido; la cuestión jurisdiccional, que resuelve la juridicidad del asunto discutido y las normas aplicables; finalmente, la cuestión legítima, que se refiere a la interpretación y es, según él, una parte especialmente oscura. Dentro de ella aparecen además problemas bastante diversos. Para clarificarlos, divide el tratamiento de la cuestión interpretativa en cuatro partes. La primera se ocupa de los problemas producidos

${ }^{64}$ Véase: Federicis, Stephanus de, De interpretatione legum, en Tractatus Universi Iuris, I, cit. (n. 64), p. 208 dorso.

${ }^{65}$ Ibíd., p. 209: "Qui enim sine locorum topice istius cognitione legis interpretari audent, his similes videntur, qui absque navi mare intrare audent, absque securri ligna incidere, sine pedibus ambulare, sine alis volare, neque pontum, neque nevigerum iter agnoscunt".

${ }^{66}$ Sobre los tratados de tópicos en el Humanismo jurídico, véase: Rodríguez Puerto, Manuel Jesús, La modernidad discutida (Cádiz, Servicio de Publicaciones de la Universidad de Cádiz, 1999), pp. 260 ss.

${ }^{67}$ Sobre la concepción de tópica en esta época y sus diferencias con las teorías surgidas en el siglo XX con ese nombre, véase: Rodríguez Puerto, Manuel Jesús, Tópica y humanismo jurídico, en Anuario de Filosofía del Derecho, 18 (Madrid, 2001). 
cuando hay discrepancia entre lo escrito en la ley y lo expresado en ellas; la segunda, de las discrepancias entre leyes que parecen contrarias entre sí; la tercera, de la ambigüedad de las palabras de la ley; la cuarta, en fin, de aquellos casos en los que la controversia no se encuentra regulada expresamente, pero puede serlo mediante la similitud con otra ley ${ }^{68}$. Son los mismos asuntos que han tratado Caepolla y Rogerio, aunque ahora aparecen de manera más ordenada y explícita. El interés por cierta claridad en la exposición parecer aumentar paulatinamente entre los juristas del ius commune. Por otra parte, este esquema no era original: había aparecido en los primeros Glosadores, procedía de la Retórica ciceroniana y también está presente de manera más o menos explícita en autores como Rogerio $^{69}$. No obstante, Federicis cita otras fuentes filosóficas, que aparecen también en juristas de la época: al principio menciona los tratados sobre hermenéutica de Boecio y Aristóteles y cita la afirmación paulina sobre la relación entre la letra y el espíritu vivificante ${ }^{70}$.

La primera vertiente de la cuestión la afronta, como ya he dicho, con la tradicional distinción entre la escritura o palabras (verba) de la ley y su mens o intellectus. También, como era habitual, proclama que la mens es más importante que las palabras, entre otros motivos porque es posible entender más cosas de las que pueden expresarse con palabras, al haber más negocios que vocablos ${ }^{71}$. Dicho de otra forma, la realidad es siempre más amplia y compleja de lo que puede recoger el lenguaje de la ley.

Entre la palabra y el espíritu de la ley puede haber coincidencia, y en tal caso se aplican ambos. Puede ocurrir también que se opongan y entonces no es posible aplicar ninguno de los dos. Cuando no son idénticos, pero tampoco se oponen, sucede que se exceden uno a otro: lo escrito tiene más amplitud que el espíritu de ley o viceversa; en tal caso es preciso ampliar o restringir las palabras de la ley, pues la ley no sólo dice lo que está escrito, sino también lo que procede de su espíritu $^{72}$. Dicho en términos actuales, este tipo de problemas no está causado por la ambigüedad o polisemia de las palabras de la ley, simplemente ocurre que el significado claro no se identifica sin más con la literalidad textual. Cuando

${ }^{68}$ Federicis, St., De interpretatione legum", cit. (n. 64), p. 280. "Prima quando plus aut minus intellectum est, quam scriptum. Secunda, quando leges invicem videntur esse contrariae. Tertia, quando verba legis sunt ambigua. Quarta quando controversia diffinita esse non reperitur, tamen a similitudine alicuius legis diffiniri posse videtur".

${ }^{69}$ Véase: Отте, Gerhard, Dialektik und Jurisprudenz (Frankfurt a.M., Vittorio Klostermann, 1971), pp. 158 ss.; también: SCHRÖDER, J., Recht als Wissenschaft, cit. (n. 32), pp. 50-51, donde cita como ejemplo de utilización de ese modelo el tratado de Federicis (p. 52). También sostiene ahí que las obras propiamente hermenéuticas derivadas del peri ermeneías de Aristóteles ejercieron menos influencia. Según Schröder los modelos del Corpus iuris fueron más fuertes que las obras propiamente retóricas, que proporcionaron sobre todo modelos para la organización externa del derecho.

${ }^{70}$ Federicis, St., De interpretatione legum, cit. (n. 64), p. 210, 1-5.

${ }^{71}$ Ibíd., p. 210: "[...] quae magis intelligi, quam verbis edici possunt [...] quia plura sunt negotia quam vocabula”.

${ }^{72}$ Ibíd., p. 210"Nam non solum id dicitur esse secundum legem, quod scriptum est, sed etiam quod ex mente". "Magis intelligi, quam verbis edici possunt [...] quia plura sunt negotia quam vocabula". 
Federicis dice que algo puede estar comprendido en la ley, aunque no esté dicho en ella, nos indica que el significado claro puede estar más allá de la literalidad pero contenido en la mens legis ${ }^{73}$. Además, la mens legis es la parte mejor de la ley, porque preservar la propiedad de las palabras exige respetar el sentido de la ley ${ }^{74}$. Con la finalidad de enseñar los medios desde los que extraer ese significado extraliteral expone una cantidad de argumentos bastante variados. Esa explicación puede dejar un poco perplejo al lector. En efecto, si esta parte del tratado no se ocupa con problemas de ambigüedad, los significados deben estar claros, incluyendo el procedente del espíritu de la ley. Sin embargo, la enumeración de criterios diversos destinados a desvelar esas discordancias entre lo escrito y lo pretendido por el autor muestra, que, en realidad, ese espíritu de la ley no tiene un carácter unívocamente homogéneo, sino que debe ser entendido según las realidades plurales y circunstanciadas que ha de tener en cuenta la ley; su significado no depende del jurista, pero tampoco es una entidad delimitada en bloque por el legislador ${ }^{75}$. Tengamos en cuenta, además, que Federicis expone esos argumentos, pero no establece una jerarquía estricta entre ellos.

Al exponer los argumentos para obtener el significado en esta parte del tratado, distingue entre la situación en la que la escritura es más estricta que el intelecto de la ley, y aquella en la que la escritura es más amplia. Los criterios para solventar esos problemas son diferentes. Entre los encargados del primer supuesto están la referencia a lo unido al texto (mostrado por la definición, las partes y el género) o lo opuesto al mismo texto. Dentro de lo contenido en el mismo texto están los aspectos sustanciales y formales de los términos, como género, especie, propio, diferencia. Otros criterios interesantes son: la naturaleza de la cosa o asunto del que se habla; el argumento a sensu contrario; el rechazo de resultados irracionales; la relación con otras leyes; las presunciones. Entre los argumentos adecuados para la restricción del significado a partir del espíritu de la ley aparecen la intención del legislador (mens ipsius legislatoris); la aparición de nuevas causas justas e inesperadas; la razón o causa de la ley ${ }^{76}$.

La mención de la intención del legislador muestra la ya mencionada ambigüedad que la noción de mens legis tenía para el derecho común. A veces parece indicar la voluntad del legislador, pero la especificación de una intención del legislador como un criterio más que sirve para conocerla muestra que no es así. Porque en realidad la mens legis no era un criterio interpretativo más, sino resultado de la interpretación. Como nos advierte Alejandro Guzmán, el sensus de la ley debía ser reconstruido y para ello entraban en acción argumentos y criterios varios ${ }^{77}$.

${ }^{73}$ Ibíd., p. 210, 10, 13: "Ex quibus intuere licet, quo quamquam verba unum tantum nostris auribus sonent, tamen aliud ultra verba ex mente loquentis nostro intellectui praestant". "[...] Itaque notandum est, quod aliquid dicitur esse in lege comprehensum, licet non dicatur".

${ }^{74}$ Ibíd., p. 120: "[...] quia a sensu legis recedendum non est, ut proprietas verborum observetur".

${ }^{75} \mathrm{Ha}$ estudiado este aspecto de la mentalidad del ius commune: CARPINTERO, Francisco, En torno al método de los juristas medievales, en Anuario de Historia del Derecho Español, 52 (Madrid 1982).

${ }^{76}$ FEDERICIS, St., cit. (n. 64), p. 213 ss.

77 Ibid. 
Por eso tampoco es identificable sin más con la causa, razón o finalidad que está tras la creación de la ley (algunos autores sí hacen esa identificación), acepción que sí funciona a veces como criterio interpretativo.

Por otra parte, cuando funciona como criterio interpretativo específico, Federicis aclara que debe ser empleada con precaución. Puede emplearse si es clara, bien porque esté expresa, bien porque puede captarse mediante argumentos fortísimos, pero no debemos descubrir la razón de la ley de manera arbitraria, ya que no debemos apartarnos de las palabras expresas de la ley a causa de una razón incierta. Si el juez pudiera apartarse de las palabras de la ley a su antojo, no tendríamos leyes fijas: el juez es ejecutor de la ley, no representante de una parte del juicio ${ }^{78}$.

Federicis subraya la relevancia en este asunto de la razón natural o escrita, porque la razón natural debe obedecerse como ley escrita. Pues así como en un mandato general no se entiende incluido aquello que el mandante no habría concedido, en la ley general no parece que pueda estar comprendido lo que el legislador no habría estatuido si hubiese sido interrogado expresamente sobre ello. Esto se explica porque la ley procede del consejo prudente y no es verosímil que la ley general comprenda un caso que un hombre bueno y prudente habría rechazado incluir, tal y como Aristóteles explica en el libro segundo de la Ética. De todo lo cual se deriva la presunción de que la ley no puede comprender una regulación deshonesta ${ }^{79}$.

Todos estos criterios sirven para adecuar el significado textual más o menos amplio a la mens legis, en la medida en que esta es determinada gracias a aquellos: a veces se adopta el significado más estrecho, otras el más amplio, como señalé más arriba, no parece haber pautas fijas para el jurista.

Diferente es el problema ocasionado por la ambigüedad de la ley ${ }^{80}$. Si hasta ahora la dificultad ha estribado en perfilar o abandonar la literalidad prima facie en aras de otro significado justificado por razones de mayor peso, este segundo conjunto de cuestiones se fija en la falta de claridad o en la pluralidad de significados. También ahora es fundamental la distinción entre mens legis y proprietas verborum, porque es preciso averiguar el significado gramatical y compararlo con la mens legis. Lo que ocurre es que no conocemos con claridad ninguno de los dos. Nuevamente si alguien busca aquí un método preciso quedará decepcionado.

${ }^{78}$ Ibíd., p. 214: “Alias autem non debemus rationem legis ex capite nostro invenire, arg. 1. non omnium $\mathrm{ff}$ de leg. Sed potius esset standum verbis legis, quia a verbis expressis non est recedendum propter rationem incertam, 1 . non aliter ff de lega 3 cum similibus, quia sequeretur, si iudex ex capite suo posset a verbis legis recedere, non haberemus legem certam et omnis lex certa subverteretur. [...]. Iudex enim dicitur executor legis, non autem cognitor".

${ }^{79}$ Ibíd., fol. 214 dorso: "[...] Ita in lege generali non videtur comprehendi tale quid legislator, si specialiter fuisset interrogatus, non statuisset ar. 1 . tale pactum, $\$$ si ff de pac. Nam cum lex fiat consilio prudentum, non esse verisimile legem generalem eum casum comprehendere, quem vir bonus et prudens non statuisset secundum Arist. in 2 Ethicorum, ex quo sequitur, quod lex generalis non praesumit comprehendere casum inhonestum, vel turpem [...]". Recordemos que para esta mentalidad el honestum estaba compuesto por los principios morales básicos, que nunca pueden obviarse. La interpretación debe respetarlos.

${ }^{80}$ Para Rogerio éste sería el objeto de la interpretación en sentido estricto. 
Además, es difícil distinguir este tipo de cuestiones de los conflictos entre mens y verba.

Reitera que la literalidad debe ceder ante el sentido o intelecto de la ley. Consecuentemente, es necesario hallar la mens legis y para ello Federicis desgrana un elenco de criterios. Nuevamente sería un error entenderla como la intención del autor, la voluntad del legislador o algo parecido, ya que los argumentos ofrecidos para su conocimiento se refieren al tipo de ley, los asuntos dispuestos en ella, la interpretación más acorde con la justicia y la razón, al significado que resulte más benévolo, o más acorde con la finalidad de la ley. Especialmente destacable es el papel desempeñado por la cualidad de la cosa o negocio del que se trate, porque, explica Federici, las palabras deben ser entendidas según la materia de la que habla la ley, pues las palabras deben servir a las cosas y no al revés ${ }^{81}$.

Él se pregunta qué hacer si diversas hipótesis sobre la mens legis se contradicen entre sí. No duda la respuesta: debemos interpretar la ley según la hipótesis más eficaz, y la más eficaz es aquélla cuya contraria es la más opuesta al espíritu de la ley y produce resultados absurdos, inútiles, injustos o imposibles ${ }^{82}$. Como vemos, la solución depende del empleo de conceptos indeterminados que requieren integración por parte del juzgador, si lo expresamos con términos actuales. Para Federicis esa integración exige ineludiblemente referencias a la justicia y racionalidad de la decisión.

La mens legis es sólo una parte del significado, si bien la más importante. La otra, como ya sabemos, es la propiedad de la palabra, que también surge tras considerar diferentes cuestiones. En primer lugar es preciso tener en cuenta que la significación de las palabras procede de lo instituido por los mayores o del uso común de los hombres de manera que ese uso puede incluso derogar la significación propia. El motivo es que los nombres son impuestos por la voluntad de los hombres y un cambio en esa voluntad los modifica ${ }^{83}$. Sin embargo, si no consta esa costumbre será preciso recurrir a la significación propia y a los criterios para elucidarla ${ }^{84}$. Entre ellos se encuentran la definición, la etimología, la adecuación a reglas gramaticales, etc.; según este último criterio, debe ser elegida la interpretación más

${ }^{81}$ FEDERICIS, St., cit. (n. 64), p. 220. "Ex qualitate rei sive negotii, de quo agitur, mens colligitur: quia verba debent intelligi secundum subiectam materiam, de qua loquitur lex, quia verba rebus servire debent, non e contra. [...] Amplius licet a verborum proprietate recedere, ut mentem legis interpretemus secundum subiectas res [...]".

${ }^{82}$ Ibíd., p. 220 dorso : "Ex praedictis erit quaestio, si plures coniecturae mentis contrarie concurrant, quae sit eligenda? Et in hac quaestione puto legem esse interpretandam secundum illam coniecturam mentis, quae magis sit efficax, sicut in testibus in simili dicitur, 1 . ob carmen, ff de testib. Et illa dicitur clarior et efficacior mentis coniectura, cuius rationis oppositum magis est contra mente legis, et ex quo magis absurdum sequeretur, puta, si oppositum concederetur, lex esset sibi contraria, vel impossibilis, vel iniusta, vel inutilis".

${ }^{83}$ Ibíd., p. 221, 63:"Notandum est, quod verborum significatio, tum ex institutione maiorum nostrorum, tum ex usu communi hominum imposita est qui communis usus hominum si probatus fuerit, derogat propriae significationi; quia sicut ex voluntate hominum rebus nomina imposita sunt, ita eorum contraria voluntate mutari, et alteri possunt".

${ }^{84}$ Ibíd.: "At si consuetudo non constat, tunc propria verborum significatio attendenda est". 
clara y más literal ${ }^{85}$. Este autor advierte, como cautela general, que el significado de las palabras lo establecen bien nuestros antepasados, bien el uso común de los hombres; el uso comprobado prevalece sobre el significado propio ${ }^{86}$.

Una vez establecidas la mens legis y la proprietas verborum, es preciso armonizarlas; esa es, recordemos, la tarea pendiente es los supuestos de ambigüedad de la ley. Caben diversas posibilidades. Si ambas están claras y coinciden adoptamos esa significación. Si el significado impropio es el que coincide con la mens legis, y no se aleja demasiado del propio, nos remitimos al impropio. Si la significación propia y la impropia están al mismo nivel, o si ninguna de ellas se acomoda al intelecto de la ley, es mejor atender a la proprietas verborum ${ }^{87}$. Como vemos, la mens de la ley es el elemento más importante en la interpretación.

La tercera cuestión interpretativa planteada por Federicis en su tratado es la aplicación de una ley a un caso no previsto en ella, pero similar a los que sí están regulados. Indica que la falta de regulación expresa de un caso puede tener lugar de varias formas. La primera, cuando el caso tiene un carácter fuera de lo natural o acostumbrado. La segunda, cuando el caso no está fuera de lo natural, sino que es producto de pasiones desenfrenadas que cotidianamente generan nuevos litigios o de la condición de la naturaleza humana pronta a producir nuevas formas. La tercera se produce con casos muy frecuentes, pero cuya materia es tan múltiple y variada que no pueden encerrarse en una doctrina cierta. La cuarta posibilidad es la omisión de un caso en la ley que, sin embargo, puede ser regulado mediante lo expresado en el espíritu de la ley; este problema lo ha estudiado ya en la primera cuestión interpretativa. La quinta tiene lugar cuando la ley regula expresamente un caso, surge después un caso nuevo que no está comprendido en la ley, pero al no ser completamente diferente al regulado puede ser incluido por similitud en la regulación expresa; este tipo de razonamiento es el denominado argumento de similis ${ }^{88}$. No obstante, establecer en que consiste la similitud no es tarea fácil. Federicis explica que a veces la palabra similitud se emplea impropiamente para referirse a la identidad o a la paridad. Pero en sentido propio es la conveniencia de los accidentes entre diversas especies ${ }^{89}$. Con esta terminología procedente de la tópica Federicis pretende indicarnos que la similitud aparece cuando hay relación entre algunos aspectos de cosas que son diferentes desde otro punto de vista. Esos aspectos pueden consistir en la concurrencia de la misma razón, del mismo efecto o potencia, o de cualquier otro tipo de parecido que pueda resultar relevante. La mención expresa que hace de la tópica aristotélica en este punto nos muestra el plano argumentativo en el que se mueve este jurista: una argumentación ceñida a

${ }^{85}$ Ibíd., p. 221, 94: “Vigesimosecundo, illa est interpretatio eligenda, quae magis plana, et secundum literam est".

${ }^{86}$ Ibíd., p. 221, 63.

${ }^{87}$ Ibíd., p. 220 dorso. Aunque a veces la proprietas verborum, es decir el signifcado propio, abarca tanto el espíritu como la letra, en este momento Federicis parece identificar la proprietas con la literalidad o verba.

${ }^{88}$ Ibíd., p. 222, 2-7.

${ }^{89}$ Ibíd., 222 dorso, 8: “Tertio modo accipitur proprie pro convenientia accidentium ad diversas species". 
los problemas y abierta a las distinciones y excepciones que surgen incesantemente en la cotidianidad. En efecto, para esta mentalidad la retórica es traslación de la diversidad de planos y facetas que caracteriza el plano de lo práctico.

La extensión del significado a casos similares presenta además una complejidad adicional. Federicis advierte que el argumento a simili es muchas veces falaz ${ }^{90} \mathrm{y}$, aunque no lo reconozca expresamente, resulta claro que eso se debe a la cantidad de razonamientos sutiles que requiere. La extensio de una ley, por ejemplo, puede depender de su carácter y de la equidad o racionalidad que contenga (una razón de derecho natural, de derecho civil, una causa adecuada o contraria a las regulae de derecho civil, etc.) $)^{91}$.

Resulta interesante al respecto el tratamiento ofrecido por Federicis de la interpretación de los estatutos. Recuerda la tradición civilista acerca de la necesidad de entender esas normas de manera tan absolutamente literal que se impida cualquier interpretación, pero considera que se trata de una exigencia de cumplimiento difícil en cada una de las partes que abarca la interpretación. Desde luego, al ser la mens legis la fuerza y potestad de la ley, es tan absurdo impedir que el estatuto pueda ser interpretado según su espíritu, como afirmar que el hombre puede existir sin alma $^{92}$. También es sensato permitir que los estatutos se interpreten utilizando otros estatutos. Y también es lícito resolver los problemas de ambigüedad de las palabras que componen el estatuto. Y en cuanto a la extensio, puede ser admisible, aunque tenga algunas limitaciones (por ejemplo, cuando se entiende que el caso omitido en el estatuto ha de remitirse a las disposiciones del derecho común). Por lo demás, dado que el estatuto ha de ser honesto, útil, posible y claro, pues de otra manera no puede ser una ley, es necesario que reciba una interpretación que impida el surgimiento de algo inhonesto, irracional o imposible desde dicho estatuto $^{93}$. La conclusión es interesante: para Federicis una aplicación puramente literal de la norma jurídica es imposible.

${ }^{90}$ Ibíud., p. 222, 14: "Multipliciter autem contingit fallacia argumenti a simili".

${ }^{91} \mathrm{La}$ equidad era un asunto que preocupó a estos romanistas desde el comienzo. La noción de equidad como concreción de la norma y su empleo en la interpretación eran conocidos por lo romanistas bajomedievales. Pero el abanico de cuestiones que abarcaba esa palabra era muy amplio y no sólo afectaba a la intepretación. Particularmente relevante fue la polémica sobre el margen que el aplicador tenía para apartarse de la ley en función de la aequitas y el papel que en esa tarea correspondía al gobernante. Véase: GuZMán, A., Ratio scripta, cit. (n. 51), pp. 12 ss.; El MISMO, Codificación, cit. (n. 4), pp. 77 ss. Sobre el uso de la equidad en la interpretación extensiva y su relación con la epiqueya aristotélica dentro del ius commune medieval, véase: Horn, Norbert, Aequitas in den Lehren des Baldus (Colonia - Graz, Böhlau, 1968), esp. pp. 20 ss., 48 ss. Es llamativo, sin embargo, que al estudiar los criterios en estos tratados sobre interpretación la equidad aparezca de una manera tan subordinada y que no sea objeto de un cuestionamiento teórico expreso.

${ }^{92}$ Federicis, St., cit. (n. 64), p. 225, 96. "Primo casu, cum vis et potestas legis in mente consistat ut d. lex scire leges, ut supra plene probavi, non potest effici quod lex non interpretetur secundum mentem, quemadmodum non posset fieri quod homo non esse sine anima [...]".

${ }^{93}$ Tras exponer la viabilidad de los cuatro tipos de interpretación, ibíd., p. 225, 101, escribe que: "et, ut generaliter dico, cum statutum debeat esse honestum, utile, possibile, et clarum, alioquin non lex, sed pestilentia dici potest 4 dist. c. erit autem lex, necesse est, ut eam interpretationem recipiat per quam ex dicto statuto nihil inhonestum, sive irrationabile, prodigiosum, impossibile, vel 
Otro aspecto que refuerza el carácter escasamente metódico de esta jurisprudencia es la posición relevante del consenso. Entre los criterios más generales sobre interpretación que expone Federicis al concluir su tratado están los que facilitan la elección entre opiniones diversas de los doctores. Y uno de ellos reza así: en caso de duda es preciso escoger la opinión aprobada por los más prudentes, aunque sean más abundantes los defensores de la parte contraria. También es mejor seguir la opinión de los mayores o la doctrina consolidada por la costumbre más antigua salvo que conste su falsedad ${ }^{94}$. Era la manifestación en el ámbito interpretativo de la communis opinio, tan relevante para estos juristas ${ }^{95}$.

A partir de lo expuesto por estos civilistas es evidente que no defendieron una actitud literalista ante el significado de la ley. Pero este tampoco era para ellos una realidad completamente maleable. Era preciso partir del significado comprendido en la norma, perfilar sus contornos, calibrar y ponderar posibilidades y argumentar la calidad de la opción escogida ${ }^{96}$. Ellos consideraban que esa complejidad argumentativa era fiel al contenido legal, porque partían de un concepto de norma ajeno a la mentalidad imperativista, a igual que Tomás de Aquino, aunque por vías propias. Piano Mortari ha escrito que los integrantes del ius commune adoptaron una visión normativista del derecho al identificarlo con las leyes de la Compilación justinianea, aunque la combinaron con una consideración racionalista, porque el derecho era producto de una voluntad racional y dependía (según Mortari) del derecho natural; de ahí que pudieran emplear los métodos racionales de la dialéctica escolástica para desvelar el sentido o razón del texto legal ${ }^{97}$. Estas reflexiones precisan alguna matización. En primer lugar, la práctica romanista está influida por la Retórica y el modo de argumentar contenido en los textos jurídicos romanos, no por una supuesta dialéctica escolástica. Pero, sobre todo, es preciso subrayar que la concepción del derecho adoptada por estos romanistas era ajena a un normativismo voluntarista. A partir de los textos justinianeos, eran conscientes de que al emperador competía la creación de normas generales, pero no se trataba del mero establecimiento voluntarista de una norma, ni siquiera matizado por cierta racionalidad. Como ha destacado Jesús Vallejo, el príncipe tenía el poder para decir el derecho (iurisdictio) tanto mediante reglas generales como en decisiones concretas. Pero ese poder no era omnímodo, sino que estaba

contrarium oriatur". La tendencia a un entendimiento literal de los estatutos estaba extendida en el ius commune, pero también había opiniones contrarias, que alegaban la imposibilidad de ese literalismo. Véase: Lange, H. - Kriechbaum, M., Römisches Recht im Mittelalter. Die Kommentatoren, cit. (n. 4), pp. 240 ss.

${ }^{94}$ Cfr. Federicis, St., cit. (n. 64), p. 225 dorso, 113-117. La raíz retórico-aristotélica de estos argumentos es clara.

${ }^{95}$ Sobre su papel vid. Lombardi, L., cit. (n. 6), pp. ss

${ }^{96}$ Los Comentadores estaban preocupados por argumentar desde la ley y conservamos testimonios suyos en los que reclaman la importancia del texto legal frente a las "sutilezas". $\mathrm{Al}$ mismo tiempo es una prueba de que muchas veces otros elementos, como la Glosa, tenían más importancia que el texto legal. Vid. las referencias en las biografías recogidas en LANGE, H. - Kriechbaum, M., Die Kommentatoren, cit. (n. 4), cap. V.

${ }^{97}$ Véase: Piano Mortari, V., Il problema dell” interpretatio iuris", cit. (n. 32), pp. 51 ss. y 88 ss. Piano Mortari, V., Ricerche, cit. (n. 32), pp. 200 ss. 
medido por exigencias de justicia y equidad (la equidad ruda), que reclamaban plasmación en las leyes; estas no creaban el ius ex novo, sino que interpretaban la equidad ${ }^{98}$. Desde este planteamiento es explicable que el contenido de la norma expresase fines, razones y puntos de vista frecuentemente irreductibles a un contenido fijado de forma imperativa; esa complejidad del contenido tenía equivalente en la complejidad de los argumentos elaborados por la doctrina para conocerlo. Estos juristas querían ser fieles a las leyes, pero a leyes que no podían ser unívocas, porque se integraban en una realidad jurídica más amplia: simplemente ellos no identificaron la lex con el ius.

\section{LAS REFLEXIONES DE LOS JURISTAS HUMANISTAS SOBRE LA INTERPRETACIÓN.}

\section{El INTERÉS POR EL MÉTODO}

A partir del siglo XV las corrientes humanistas influyeron en el estudio del derecho romano y de esa confluencia surgió una peculiar corriente romanista denominada Humanismo jurídico. No fue una corriente homogénea. Algunos de sus representantes se empeñaron sobre todo en la depuración filológica e histórica de los textos romanos, y han sido considerados por la historiografía seguidores de un mos gallicus de estudiar el derecho. Sin embargo, como ha mostrado Francisco Carpintero, hubo una corriente amplia de juristas que, inspirados por los studia humanitatis pero también por una preocupación específicamente jurídica, otorgaron un papel fundamental a la razón en su tratamiento del derecho; de ahí que puedan ser considerados, utilizando la expresión acuñada por Carpintero, representantes de un "Humanismo racionalista" 99 . Entre sus objetivos estaba ordenar metódicamente el material jurídico. Ellos entendieron el método como una forma ordenada de exponer los contenidos habituales del ius commune a partir de nociones jurídicas generales ${ }^{100}$. Cabe pensar que, movidos por esa ambición, trataron de manera metódicamente rigurosa la interpretación. Las fuentes, sin embargo, nos muestran una situación algo diferente.

Desde luego, no aparece ese método en uno de los iniciadores del Humanismo jurídico, Andrea Alciato. Dedicó a la interpretación un tratado titulado De verborum significatione en el que, como indica Piano Mortari, une la cultura humanista con la doctrina interpretativa ya fijada por la jurisprudencia tradicional ${ }^{101}$. Alciato comienza afirmando que las palabras han sido creadas para expresar la sentencia proferida por el hablante y que, en consecuencia, es preciso atender en primer lugar a su voluntad. Esa voluntad se conoce a partir de lo que las palabras mismas

${ }^{98}$ Véase: Vallejo, Jesús, Ruda equidad y ley consumada. Concepción de la potestad normativa (1250-1350) (Madrid, Centro de Estudios Constitucionales, 1992), pp. 40 ss., 63, 302 ss. Un estudio general sobre la diversidad de acepciones del término iurisdictio en el pensamiento bajomedieval es el de Costa, Pietro, Semantica del potere politico nella pubblicistica medievale (1100-1433) (Milano, Giuffrè, 1969), especialmente las pp. 134 ss. dedicadas al papel del príncipe al establecer las normas a partir de un "orden del mundo" previo.

${ }^{99}$ Véase: Carpintero, F., “Mos Italicus”, “mos Gallicus”, cit. (n. 9), pp. 108 ss.

${ }^{100}$ Sobre la noción de método en el Humanismo jurídico, véase: Rodríguez PuerTo, M.

J., La Modernidad discutida, cit. (n. 66), cap. IV per totum.

${ }^{101}$ Cfr. Piano Mortari, V., Ricerche, cit. (n. 32), p. 14. 
indican. Según Quintiliano, a quien cita Alciato, el conocimiento de las palabras a su vez se obtiene a partir de cuatro instancias: la propiedad, la impropiedad, el uso y la interpretación ${ }^{102}$. Reparemos en que la interpretación es sólo una de las maneras de conocer el significado de las palabras. Alciato enlaza así con una tradición antigua, como ya indiqué más arriba al referirme a Constantino Rogerio. En efecto, Alciato también reserva el vocablo interpretatio para la extensión del significado de la ley a casos similares.

Este jurista cita a Bartolo para sostener que la propiedad de las palabras se extrae de tres modos: desde la autoridad, la definición y la etimología. Alciato matiza que las definiciones no son del todo fiables, tal y como ya advertía Celso. La definición es la exposición de la substancia de las cosas comprimida de manera breve y apropiada, conteniendo género, especie, propio, diferencia (como dice Quintiliano), pero, en opinión de Alciato, no se encuentra mucho de este estilo en el derecho, porque los jurisconsultos dejaron a los dialécticos estas sutilezas y se sintieron satisfechos con describir la substancia de la cosa mediante una regla común ${ }^{103}$. Parece que Alciato prefiere los modos de razonar típicamente romanistas a las sutilezas dialécticas. Esa fidelidad la muestra al explicar que el significado propio procede de la interrelación entre las palabras (es decir, la literalidad) y el espíritu de la ley. En principio, en cualquier materia debemos tomar las palabras en la medida en que las muestra la propiedad del discurso. Sin embargo, hemos de abandonar ese criterio si conocemos que la intención del hablante es otra; esa intención se discierne más fácilmente en la disposición de la ley (la finalidad) que en las palabras de los hombres ${ }^{104}$. Repite, como todos los romanistas, que la ley no consiste tanto en la forma de las palabras como en su razón. Si el significado propio de las palabras coincide con lo dispuesto en la ley, nos ceñimos a las palabras, porque una hipótesis sobre el espíritu de la ley no prevalece sobre las palabras $^{105}$. Plantea, por tanto, una cierta presunción a favor de la literalidad. Si el espíritu de la ley aparece claramente, prevalece éste; si no está claro, debemos quedarnos en el significado literal.

En el primer libro, que dedica al significado propio, Alciato se ocupa de las

\footnotetext{
${ }^{102}$ AlCiATO, Andrea, De verborum significatione, en Opera omnia in quattuor tomos legitime digesta (Frankfurt, 1617), col. 1, 1: "Cum inventa sint verba, ut dicentis sententiam exprimant, merito eius voluntas in primis expectanda est, l. Labeo de supel. legg. cognoscitur autem ex eo, quod verba ipsa indicant. Haec quatuor modis accipiuntur, ex proprietate, ex improprio, ex usu, et per interpretationem".

${ }^{103}$ Ibíd., col. 758: "Sed hasce subtilitates Iurisconsulti Dialecticis reliquerunt: ipsique satis habuerunt, si substantiam rei ex communi regula describerent"..

${ }^{104}$ Kriechbaum, M., Verba und mens in den Interpretationslehren des Humanismus, en SCHRÖDER, J., (editor), Theorie der Interpretation, cit. (n. 54), pp. 50 ss. piensa que el ius commune diferenciaba entre verba y mens para dar primacía a la segunda, mientras que Alciato busca coordinar ambas nociones para extraer el significado; las palabras sirven precisamente para expresar la mens o sensus. Cfr. Me parece, sin embargo, que se trata de variaciones de matiz y que la exposición de Alciato sigue el carril establecido por la iurisprudentia de los siglos anteriores, que acababa entrelazando verba y mens para obtener la solución justa.

${ }^{105}$ Alciato, A., cit. (n. 102), col. 761, 25: "Id pronuntiatum quatuor sectiones recipit. Prima est, cum dispositioni legis verba ex proprietate conveniunt, licet mens alia praesumatur, tunc stamus verbis: quoniam coniectura mentis verborum proprietati succumbit".
} 
relaciones verba-mens y de la ampliación o restricción del significado para su adecuación recíproca. De manera tópica, es decir, a partir de lugares como las características de la persona, el tiempo, el lugar, la noción de bueno, la necesidad, etc. perfila casuísticamente las posibles modulaciones del significado propio de las palabras. Este proceder es muy similar al de los romanistas defensores del mos italicus. La claridad y del ámbito semántico de la mens legis, no están dadas de una vez por todas, sino que requieren una determinación argumentada.

Tras la exposición del significado propio, dedica el segundo libro al impropio. Puede emplearse en ciertas circunstancias, como la presencia de una causa razonable, justa, útil, etc ${ }^{106}$. Alciato también emplea aquí topoi más afines a la nueva retórica humanista. Sin embargo, previene frente a un uso excesivo de esos lugares, porque los dialécticos se esfuerzan con las palabras, mientras que los juristas tratan de las razones de las leyes con independencia de las disquisiciones dialécticas sobre similitudes o diferencias puramente verbales ${ }^{107}$.

En el tercer libro, Alciato describe el papel del uso o costumbre en la determinación del significado. Siguiendo la tradición del ius commune y de la retórica clásica sostiene que las palabras se entienden generalmente en cualquier materia jurídica a partir del uso, e incluso prevalece sobre el significado propio, aunque ese uso debe estar basado en la "autoridad de los prudentes"108. No obstante, ese significado proporcionado por el uso puede ceder a veces ante otros criterios; cuando hay dudas sobre esa significación conformada por el empleo, pero la ratio legis está de acuerdo con ella, podemos dejar de lado el significado propio; si no existe esa coincidencia con la ratio legis, deberemos ceñirnos a la proprietas ${ }^{109}$.

En el cuarto libro aparece la interpretación como modo específico de conocer el significado, identificada sólo con la extensión mediante el argumento a similis. Alciato explica que a veces la fuerza de las palabras no es capaz de expresar completamente su significado; en tales ocasiones, el significado es inducido mediante una extensión. Quien tiene jurisdicción puede proceder de lo similar a lo similar; es similar el caso que está fundado en una razón igual o mayor que la de otro y tiene el mismo efecto, aunque las palabras sean diferentes. Es suficiente que la similitud entre los casos lo sea sólo de aquel respecto del que se trate y que en lo demás haya diferencias ${ }^{110}$. Esta interpretación puede llevarse a cabo regularmente, aunque está excluida de tres tipos de leyes: las correctivas, las penales y las limitadoras.

${ }^{106}$ Ibíd., cols. 784 ss.

${ }^{107}$ Ibíd., col. 806, 74 .

${ }^{108}$ Ibíd., col. 789, 17. Aunque el reconocimiento de la costumbre como intérprete está ya en el Derecho Romano, Alciato muestra aquí la relevancia que tenía también para la mentalidad inspiradora de los romanistas, tanto medievales como humanistas. Sobre la importancia concedida por los humanistas en general al uso en el lenguaje, véase: GonZÁLEZ, G., cit. (n. 15), pp. 150 ss.

${ }^{109}$ Alciato, A., cit. (n. 102), col. 790, 17: "Sed et quoties aliqua dictio ex communi usu latius accipitur, quam ex proprietate soleret, in dubio ex proprietate accipienda est, si ratio legis non aeque ex communi usu militet".

${ }^{110}$ Ibíd., col. 792, 38-39: "Ex interpretatione sensus legis accipitur, cum vis verborum id non significat, sed extensio inducit: de similibus enim ad similia, ei qui iurisdictioni praeest, procedere fas est, l. non possunt de legibus atque ita omnis dicere. Similis autem ille casus existimatur, 1. non 
Acerca de este asunto es interesante la diferencia que Alciato establece entre la interpretación de las leyes por una parte y la de contratos y testamentos por otra. Sostiene que al llevar a cabo esa extensión desde un contrato o testamento a un caso omitido surgen más discordias que en la extensión de una ley. La causa de la diferencia reside en que la disposición de la ley obliga a partir del espíritu solo; ese espíritu o razón no tiene menos vigor por carecer de plasmación explícita en las palabras de la norma, pues no vulnera menos la ley quien obedeciendo sus palabras descuida la razón que el defraudador de ambas. Alciato afirma que conocer las razones de la ley y argumentar desde ellas es más fácil, porque podemos entender como parte de su contenido lo que el legislador verosímilmente habría establecido si hubiera sido preguntado por el caso no expreso, es decir, podemos argumentar según lo bueno y equitativo (y cita a Aristóteles y la Glosa como apoyo). Sin embargo, discernir las voluntades de los hombres en contratos y testamentos es mucho más difícil, porque los deudores siempre negarán la deuda y el acreedor afirmará lo contrario, en función cada uno de su utilidad ${ }^{111}$. Como vemos, Alciato defiende una concepción de la ley teleológicamente racional. Era la postura común entre los juristas del ius commune.

Ya he mencionado la preferencia de Alciato por los procedimientos específicamente jurídicos frente al Humanismo puro; pruebas adicionales son la defensa de los juristas frente a las críticas de Lorenzo Valla, y la mención de una serie de palabras empleadas por los juristas que Angelo Poliziano, interrogado por Bartolomeo Socino, fue incapaz de entender ${ }^{112}$. Alciato parece decirnos que en la interpretación del derecho vale más el conocimiento de los problemas propiamente jurídicos que la sutileza filológica y que, en consecuencia, son más útiles los argumentos tradicionales de los juristas que los lugares comunes de la dialéctica. Es comprensible que no mostrara interés por una ordenación metódica de la cuestión interpretativa. Pero quizá otros representantes conspicuos del Humanismo jurídico ofrecieran mayor avance metódico.

En realidad, algunos de esos humanistas, los que forman parte del mos gallicus, parecieron estar más interesados en la precisión filológica que en el estudio de

solum $₫$ qui primipilum de excom. tut qui eadem vel maiore ratione nititur quique eiusdem effectus est, tametsi verbis sit dissimilis: satisque est si similitudo sit eius respectu, de quo agitur, licet in caeteris differat".

${ }^{111}$ Ibíd., col. 807, 1: "Ad haec rationem legis perscrutari plerunque facile est, ex eaque argumentari concessum est, cum generaliter proditum est, id pro statuto habendum, quod legisladores, si de eo casu interrogati fuissent, verisimiliter constituissent: 1. tale. $\$$ fin. de pact. in Glossa quem ek tes epieikeias, id est, ex bono et aequo accipi, Aristoteles Moralium v. auctor est. At rationes hominum in ultimis voluntatibus discernere difficile est, in contractibus longe difficilius, cum semper devenit reus negaturus sit, ne productio fiat, creditor propter utilitatem sit affirmaturus". Conviene recordar, como hace Alejandro Guzmán, que en un plano general muchos integrantes del Humanismo jurídico tendieron a ver el derecho como un arte de interpretar la ley según las exigencias del bonum et aequum. Y el derecho romano mismo era ejemplo de equidad. Cfr. GuZMAn, A., Ratio scripta, cit. (n. 51), pp. 61 ss.

${ }^{112}$ Alciato, Andrea, cit. (n. 102), col. 848: "[...] cuius vocis significatione interrogatus a Socino Angelus Politianus, obmutuit, quam tan gloriatus esse in glossematis iuris civilis se vel Accursium superare posse".. 
los criterios útiles para la interpretación típicamente jurídica. Guillaume Budé se limita a indicar en sus Anotaciones a las Pandectas que toda cuestión jurídica versa sobre la propiedad de las palabras, la disputa sobre lo equitativo y la conjetura de la voluntad ${ }^{113}$. Cita a Cicerón, aunque esa concepción de la quaestio iuris está en Quintiliano ${ }^{114}$. Especialmente ácido contra los integrantes del Humanismo jurídico, Alberico Gentili (1550-1608) escribirá que en la interpretación etimológica los nuevos intérpretes (es decir, los Humanistas) son muy valiosos, pero en la analógica, que es la propia de los juristas, valen muy poco ${ }^{115}$.

Otro prestigios jurista francés, François Le Douaren (m. 1559), afirma que el derecho puede ser cierto o dudoso. En el primer supuesto no cabe interpretación, sino obediencia, aunque no nos conste la ratio del precepto, porque es estúpido inquirir las razones de las leyes ciertas constituidas por los mayores. La búsqueda de la ratio sólo es admisible si el texto es dudoso y, en tal caso, es precisa la interpretación. Para solucionar este problema tenemos que recurrir a la discusión sobre lo equitativo y la voluntad. Recordemos que son los aspectos de la cuestión jurídica enunciados por Quintiliano (que Budé había recordado en su libro sobre los Digesta). Esta es la manera de averiguar el sentido y el espíritu de la ley, que es precisamente la finalidad de la interpretación. Añade que todas las cuestiones sobre este asunto interpretativo pueden referirse a uno de los siguientes cuatro lugares retóricos: el problema de la ambigüedad, el de la relación entre escritura y sentencia; el razonamiento o silogismo (es decir, la extensión desde lo previsto expresamente en la ley); y finalmente las contradicciones entre leyes ${ }^{116}$. Se trata de la misma partición retórica que inspiraba el tratado de Federicis. Lo cierto es que Le Douaren no plantea puntos de vista novedosos sobre el problema interpretativo, a excepción del uso de una abundante erudición clásica, tal y como exigía el Humanismo jurídico ${ }^{117}$. Estas reflexiones tienen un carácter programático y no son detalladas, pero sí es perceptible en ellas la búsqueda de una simplicidad frente a los catálogos de criterios interpretativos redactados por los bartolistas. La querencia por la claridad y sencillez propias del método propugnado entonces debió de influirle. No es extraño que un Humanista como Luis Vives manifestara su desagrado por las complejidades de los juristas y quisiera limitar la interpretación a unos doctos varones que actuaran de manera hermética, aplicaran sólo la fuerza de la razón y evitaran "sutilizar la casuística"118. No todos los Humanistas pensaban así. Philip Melanchthon cita a Aristóteles para afirmar que se debe juzgar siempre

${ }^{113}$ Véase: BudÉ, Guillaume, Annottationes ad Pandectas, p. 42.

${ }^{114}$ Quintiliano, Marco Fabio, De institutione oratoria, lib. XII, cap. $2^{\circ}$.

${ }^{115}$ Gentili, Alberico, cit. (n. 9), p. 74.

${ }^{116}$ Le Douaren, François, In primam partem Pandectarum, en Opera omnia (Lyon, 1554), cap. $5^{\circ}$, p. 8 .

${ }^{117}$ Sobre el uso de citas de autores de la Antigüedad como autoridades jurídicas dentro del Humanismo jurídico, véase: Carpintero, F., “Mos italicus", “Mos gallicus”, cit. (n. 9), pp. 143 ss.

${ }^{118}$ Véase: VIVES, Luis, Las disciplinas, parte II. lib. V, en Obras Completas (trad. de L. Riber, Madrid, Aguilar, 1947. Reprint de la Generalitat Valenciana, 1992), p. 668. 
según leyes evitando así el arbitrio de los jueces, pero critica a los que pretenden conocer el derecho escrito sin las disputaciones de los intérpretes ${ }^{119}$.

Otro representante del mos Gallicus, François Hotman (1524-1590), dedicó un tratado a la interpretación y adoptó un concepto muy extenso que abarca todas las actividades del jurista. En efecto, la divide en gramática, dialéctica y específicamente jurídica. Las dos primeras atienden a la organización del material jurídico según los métodos recordados por el Humanismo, como el análisis y la síntesis $^{120}$. La jurídica trata de la solución de las controversias concretas, y Hotman las estudia según ejemplos proporcionados por el derecho romano y por retóricos como Cicerón, sin referencias a juristas bajomedievales, según es habitual en el mos Gallicus. Sin embargo, los problemas planteados son los propios de la tradición romanista: conflicto entre el derecho y la equidad; ambigüedad del texto jurídico escrito; disparidad entre lo escrito y su sentencia (que entiende como intención del autor sobre todo en los contratos); oposición entre normas ${ }^{121}$. Hotman no expone criterios interpretativos sino casuística romana que resuelve problemas variados que plantea la interpretación. La adopción de un modelo retórico para exponer esos ejemplos muestra la adhesión a un razonamiento alejado de rigideces metódicas.

Otros juristas de la corriente humanista interesados por el método se demoraron más en el estudio de los criterios interpretativos. Recordemos la distinción establecida por Francisco Carpintero entre los empeñados en la vertiente más filológica del sabe jurídico y los interesados en una jurisprudencia práctica renovada proclives a un empleo más libre de la razón que les llevó a buscar la ordenación metódica del derecho ${ }^{122}$. Uno de estos últimos fue Jean Coras (1513-1572). Escribió un tratado con la finalidad de exponer directrices metódicas para el derecho titulado De iuris arte liber. Su parte cuarta la dedica a la interpretación del derecho y, de manera típica, abarca en ese concepto todo lo referente a la determinación de la solución jurídica.

Según lo escrito por Quintiliano (a quien no cita en este punto, aunque sí en otros lugares) explica que toda cuestión jurídica versa sobre la significación de las palabras, la discusión de lo equitativo y el descubrimiento de la voluntad. Coras prefiere, sin embargo, otra división en dos géneros que según él ha sido adoptada por los que escriben sobre lugares comunes o tópicos: en primer lugar el jurista ha de encontrar el significado de palabra y acciones; en segundo, una hipótesis sobre la voluntad, que se obtiene desde la razón de lo bueno y equitativo. Coras comienza con el significado de las palabras. Explica, siguiendo al Digesto, que las

${ }^{119}$ Véase: Melanchthon, Philip, Oratio in promotione cuiusdam iurisconsulti, habita a Doctore Sebaldo Munstero Res non iudicandas secundum arbitrium iudicis sed secundum scriptum ius (1532), p. 211; Oratio publice habita Vuittenbergae in promotione Doctores iuris de scripto iure et dignitate veterum interpretium iuris (1539), pp. 229-230; editadas en KISCH, Guido, Melanchthons Rechts- und Soziallehre (Berlín, De Gruyter, 1967).

${ }^{120}$ Véase: Hotman, François, Iurisconsulti sive de optimo genere iuris interpretandi liber, en Cynosura Iuris (Spira, 1588), pp. 125 ss.

${ }^{121}$ Ibíd., pp. 133 ss.

${ }^{122}$ Véase: Carpintero, F., “Mos Italicus”, “mos Gallicus”, cit. (n. 9), pp. 135 ss. 
leyes constan de dos componentes: la escritura y la sentencia. Y añade que las palabras sirven para expresar la intención del que habla, de su autor; este resulta el elemento más importante: las leyes se identifican con su sentido, no con sus palabras $^{123}$.

Advierte que a veces es difícil conocer la sentencia de la ley a causa de la ambigüedad de la oración o la diversidad de significados de las palabras de la ley. Coras recuerda que se trata de una cuestión tan frecuente entre los jurisconsultos que constituye buena parte de su trabajo. En estos casos es mejor no dirigirse directamente al significado propio de las palabras, sino al uso acostumbrado en la región, porque como decía Sulpicio Apolinar, la costumbre es señora de todas las cosas y sobre todo de las palabras, pues ni desde la propiedad ni desde la opinión particular deben entenderse las palabras. La clave está en el uso común y la costumbre de la comunidad, como recuerda Celso en los Digesta ${ }^{124}$.

Si este recurso es ineficaz, es decir, si la oscuridad del texto no pueda aclararse mediante el uso común de los hablantes, habrá que recurrir al significado propio. Es discernible de tres modos: acudiendo a la autoridad, a la etimología y a la definición, que entrarán en acción de manera jerárquicamente descendente. Si estos indicios no son suficientes el jurista acudirá a lo que precede y sucede a la ley. También a la razón de la ley (ratio legis), es decir el fin material desde el que se rigen las palabras de cada ley y reciben la interpretación. Al fin y al cabo, confiesa Coras, la ratio legis es cierta ley tácita como dice el jurisconsulto (ley cum ratio de los Digesta); no es casual además que la palabra griega para ley, nomos, procede de nous o sentido racional, tal y como enseña Platón ${ }^{125}$.

Junto al significado propio (cognoscible empleando los criterios anteriores) está el significado impropio. Es el que aparece cuando una cosa no es nombrada con su propio nombre, sino con el de otra. Lo que preocupa aquí a Coras es el conflicto entre significado propio e impropio. ¿Cuál debemos elegir? En principio debe aceptarse el significado propio, salvo la evidencia de que el autor quiso otra

${ }^{123}$ Coras, Jean, De iuris arte liber, en Tractatus iuris universi, cit. (n. 64), I, parte IV, cap. I, p. 75. "Quotie vero iuris omnis quaestio, vel significatione verborum, vel aequi disputatione, vel coniectura voluntatis continetur. Qui de locis communibus scripserunt, duo potissimum facere genera, alterum significationes rerum et verborum, alterum coniecturae voluntatis, quae ex boni, et aequi ratione maxime colligitur. Haec nos singulatim, et diligenter exequemur, et circa verborum significationem, illud primum novisse oportet, legem duabus constare partibus, scripto videlicet et sententia, 1. scire, ff, de legibus, c. praeterea, de verb. sig. Cumque inventa sint verba, ut loquentis mentem exprimant, l. Labeo, ff, de sup. Leg. Cic. pro Cecinna ea praesumitur esse legis voluntas, quam verba significant, l. prospexit, ff, qui et qui. neq. temere putandum, aliud quem sensissem, quam quod verbis expressit".

${ }^{124}$ Ibíd: "Difficile est, vel propter orationis ambiguitatem, vel variam verborum significationem, ex legis contextu sententiam eruere, indique frequentissima illa, inter Iurisconsultos, scripti e voluntatis quaestio, e qua bona nostri Iuris, pars (inquit Fabius) dependere videtur. Fabio Quintiliano lib. 7 Oratoriae Institutiones cap. 7. Melius tamen est, in eo conflictu, non protinus scrutari, (sicuti Paulus dicit) propriam verborum significationem, sed usum moremque regiones, 1 . cum de lanionis $\$$ I ff de fun. Intr. Consuetudo enim dicebat Sulpitius Apollinaris, cum omnium domina rerum, tum maxime verborum. [...] Nec tam ex verbi proprietate, aut ex opinionibus singulorum, quam ex comunne usu (inquit Celsus) et civitatis consuetudine, nomina exaudire, intelligique debent, 1. Labeo.).

${ }^{125}$ Ibíd., parte IV, cap. $2^{\circ}$, p. 75. 
cosa y que el significado propio repugne al espíritu de la ley; en este supuesto es preciso dejar de lado la propiedad de las palabras y seguir la sentencia de la ley ${ }^{126}$. Coras piensa que no podemos abarcarlo todo satisfactoriamente en el texto de la ley a causa de las diversas circunstancias que surgen cotidianamente: por eso a veces dejamos la propiedad de las palabras y adoptamos la impropia a partir de la ratio legis ${ }^{127}$.

La consecución de un resultado razonable también debe ser considerada en la interpretación. Al ocuparse de los problemas de ambigüedad del discurso, Coras explica que deberemos escoger el significado que regule el asunto de la manera más correcta. Por eso también habremos de aceptar el significado impropio cuando el propio conduce a un resultado absurdo; y es que las palabras de la ley siempre deben ser interpretadas evitando el absurdo ${ }^{128}$.

El esquema que sigue Coras es típico de los romanistas: determinación del significado propio, solución de conflicto entre literalidad y espíritu, eliminación de la ambigüedad de las palabras y extensión del significado. Encontramos la misma confusión (intencionada) entre razón, fin de la ley e intención del autor que está igualmente presente en los juristas medievales. Porque si escribe que la mens es el alma de la ley (y puede ser entendida como la voluntad del autor), también afirma que la razón final o causa de la ley es su alma y fuerza, y añade que toda la fuerza y poder de la ley consiste en la razón ${ }^{129}$.

Esta relevancia de la razón de la ley es más patente aún en el tratamiento de la extensión y restricción del significado, aunque aclare que conviene ser cauteloso en esta práctica: no hay argumento más peligroso en el derecho que el argumento a similis a causa de los razonamientos difíciles que exige. Tal y como pensaban los romanistas, Coras explica que para su empleo es fundamental la atención a la ratio del precepto; a partir de sus explicaciones colegimos que por tal entiende la finalidad, el bien o la utilidad que acoge la norma ${ }^{130}$.

Finalmente, la interpretación, para Coras, abarca también otros asuntos: la de los contratos, la de las acciones humanas (hoy diríamos la determinación de los hechos) y también el estudio de las formas de argumentación que sirven para llegar a una conclusión, como el silogismo y el entimema ${ }^{131}$. En suma, todos los aspectos que, desde el punto de vista de un romanista, afectan a la decisión sobre un caso.

Es perceptible en este autor mayor atención por el orden en la exposición y sobre todo una ordenación más jerarquizada de la intervención de los criterios

${ }^{126}$ Ibíd., parte IV, cap. $4^{\circ}$, p. 76.

${ }^{127}$ Ibíd., p. 76: "[...] quas ob emergentes quotidie factorum varietales, scripto satis complecti non possumus: verborum proprietate relicta, amplectimur impropriam, lege si tibiff. si certum petatur, neque enim oportet captari verba, sed qua mente dictum sit, animadvertere, l. penul. ff ad exhib.".

${ }^{128}$ Ibíd.

${ }^{129}$ Ibíd., p. 76 dorso: "Etenim ratio finalis, est causa legis, et veluti anima, vigorque eiusdem: 1. scire legis $\mathrm{ff}$ de legibus. [...] Cum itaque tota vis et potestas legis in ratione consistat, $1 \mathrm{scire}, \mathrm{ff} \mathrm{de}$ legib". Coras cita aquí la ley Scire leges del título De legibus, libro primero, de los Digesta, que, sin embargo, no contiene la palabra ratio.

${ }^{130}$ Ibíd., cap. 8, p. 77.

${ }^{131}$ Ibíd., caps. 10 ss, p. 77 dorso ss. 
interpretativos. Esta tendencia la comparten otros juristas de la época. En efecto, a partir de mediados del siglo XVI tratados aparecen extensos con la misión de recoger metódicamente el contenido de todo el derecho. En esta línea es destacable la aportación de Joachim Hopper (1523-1576), uno de los juristas humanistas más preocupado por una exposición incipientemente sistemática de la realidad jurídica. En su obra más importante, el Seduardus o Sobre la verdadera jurisprudencia, Hopper concibió esa tarea a modo de escalonamiento de sucesivas concreciones desde los principios de la justicia, pasando por la legislación hasta llegar a la decisión concreta a partir de la ley. La segunda parte de esa obra está dedicada a la Dicastica, encargada de hacer efectivas las leyes para que la justicia se difunda por la comunidad; entre sus tareas está la interpretación del derecho y la ley (él hace la distinción), que consiste en la comprensión de esas realidades ${ }^{132}$. Hopper es aficionado a multiplicar las clasificaciones y divide la interpretación en múltiples facetas y clases. No voy a transcribirlas todas ahora, sólo me interesa destacar la que diferencia entre interpretación escolástica, forense y política.

La escolástica es la que tiene un carácter más metódico, porque es precisamente la que emplea los criterios interpretativos tradicionales. Puede ser simple y perfecta; la primera busca el sentido de las partes, capítulos y títulos en los que están situadas las leyes. La perfecta se encarga de las leyes individualizadas; en este plano es preciso primeramente interpretar el título en el que se inserta la ley; tras esta fase llega por fin la ocupación con la ley individual mediante la atención a cuatro aspectos: aquello colocado en la misma ley; la razón de la ley, que está por encima de la misma; la fuerza y efecto que emana de ella; por fin, la solución de oposiciones o antinomias entre leyes ${ }^{133}$. A estas facetas corresponden nombres respectivos: histórica, etimológica, práctica y analógica.

La histórica inquiere lo querido por la ley; para ello hay que establecer el texto y luego su significado. Aunque no lo diga así, parece que Hopper defiende el carácter inicial del significado gramatical cuando escribe que primero se atiende a las palabras, luego a la cosa. En segundo lugar interviene la interpretación etimológica, encargada de indagar la razón de la ley. Hopper distingue al respecto entre la ratio, la causa y la ocasión. La primera está ínsita en la misma naturaleza y es el asunto en función del que se elabora la ley; la causa parece ser un motivo más circunstancial que lleva a esa legislación específica; finalmente la ocasión mira la oportunidad adecuada para que la ratio de la ley se implante efectivamente ${ }^{134}$.

${ }^{132}$ Véase: Hopper, Joachim, Seduardus sive De vera iurisprudentia ad regem libri XII (Amberes, 1590), lib., IV, tit. $11^{\circ}$, p. 115 . El rey al que está dedicado el Seduardus-que fue publicado por los hijos de Hopper- es Felipe II de España. La obra tiene forma de diálogo. Sobre sus concepciones sobre la creación de las leyes y su aplicación vid. Rodríguez PuerTo, M. J., La Modernidad, cit. (n. 66), pp. 380 ss.

${ }^{133}$ Hopper, J., Seduardus, lib. IV, tit. 5, p. 117: "Nunc singularum autem legum quonam modo fit interpretatio? $G$. Ea vero quattuor omnino rebus constat. S. Quibus vero illis? $G$. Una, quae legis ipsius est, et in ipsa collocate; altera, quae rationis legis, et supra eam est posita; sequens quae vis eius et effectus, et ex illa effluit infraque illam descendit, et utilma, mixta, quae plures leges inter se comparans, pugnam earum, quam antinomiam vocant, dissoluit".

${ }^{134}$ Ibíd., lib. IV, tit. XVII, p. 119: “G. Inter quae quidem tria hoc interest, quod ratio est quae in natura ipsa est insita, sive res qua de lex facienda est, adsit, sive non sit. [...] Causa est, 
La siguiente es la denominada interpretación práctica, que busca la fuerza y efecto de la ley, porque conocer la ley no es atenerse a sus palabras, sino a su fuerza y potestad. Se trata de exponer el contenido tácito de la ley; de ahí la extensión o restricción del significado legal. En cambio, la analógica se ocupa de solucionar los conflictos entre leyes. De manera algo confusa, Hopper ya ha incluido en la previa Nomothetica la interpretación extensiva y restrictiva, como modos de difundir las leyes en la comunidad política ${ }^{135}$.

Estos procedimientos son para juristas académicos. La solución judicial de los problemas concretos pertenece a la que denomina interpretación forense. Aunque debe estar dirigida por los criterios expuestos por la interpretación escolástica, Hopper admite aquí que la cuestión es más complicada y no ofrece ningún procedimiento prefijado para aplicar criterios y preceptos. Aquí entra tanto la determinación de los hechos como del significado de la ley ${ }^{136}$. Están incluidas la interpretación en sentido estricto y la extensión o restricción del contenido legal en función del problema, ya que la primera tarea consiste en invenire quaestionem, es decir, determinar aquello de lo que debe juzgarse o, dicho de otra forma, explicitar las características del problema que reclama solución ${ }^{137}$. Esta actividad interpretativa resulta bastante abierta a consideraciones prudenciales.

Es interesante señalar la preocupación de Hopper por defender el papel del legislador. Por eso la interpretación política es la realizada por los mismos encargados de crear las normas, que vigilan si éstas han sido elaboradas correctamente. Esta labor no debe desenvolverse en la escuela, porque en ellas se enseña a los jóvenes a amar las leyes como a diosas, no a enjuiciarlas; tampoco en el tribunal, porque su misión es el juicio según leyes y no el juicio de las leyes mismas. Los encargados de esta interpretación son una especie de "guardianes" próximos a los legisladores, ya que es tarea próxima a la legislación ${ }^{138}$.

cum non solum ratio, verum etiam res adest, quae legem fieri suadet. [...] Occasio est, quae post rationem et causam, opportunitatem constituendae legis tribuit, quae saepe expectanda est, ut aptius latio legi cadat".

${ }^{135}$ Ibíd., lib. IV, tit. III, pp. 109-112.

${ }^{136}$ Ibíd., lib. IV, tit. XXII, pp. 121 ss.

${ }^{137}$ Ibíd.: "Deinceps quaestiones fori quas vocas? G. Per quas a rebus ad leges ascenditur, ut per reas examinentur, quo pacto, iuste se habeant, nec ne. S. Id autem quibus modis ftt? G. Inveniendo ac diiudicando. S. Invenire quid vocas? G. Certa ratione ac via investigare, quidnam sit id de quo quaeritur, et quale. S. Quid nam sit de quo quaeritur, quo pacto invenitur? G. Si de quaestione constet primo, deinde autem de eo quod est iudicandum. S. Quomodo constare potest de quaestione? $G$. Si in quaque controversia tum quidem intentionem auctoris spectes; tu, debes mihi centum ex mutuo: tum autem depulsionem rei; non debeo. Hinc enim continuo liquet, quaestione esse, utrum centum ex muto debeantur, nec ne".

${ }^{138}$ Ibíd., lib. IV, tit. $28^{\circ}$, p. 122: "Haec abeo nomen habet, quod in senatu ac republica, ubi de legibus condendis et corrigendis agitur, et utrum recte latae sint nec ne inquiritur, potissimum versatur; et ideo neque in communibus scholis tractari debet, ubi leges ipsas iuvenes, non autem iudicium de legibus, quas ut deas colere oportet, addiscere debent; neque in foro ac tribunali, ubi secundum leges non de iis est iudicandum". Llama la atención la similitud de esta interpretación con las tareas desempeñadas por la casación del siglo XIX y por los tribunales constitucionales actuales. Claro que no hay que exagerar la actualidad de este planteamiento: en el Antiguo Régimen potestades legisladoras y judiciales no estaban deslindadas, todas eran parte de la iurisdictio. 
Otro jurista muy preocupado por la sistematización del derecho y el papel desempeñado por la legislación fue Hughes Doneau (1527-1590), aunque sus presupuestos fueran diferentes a los de Hopper. Cabe preguntarse si esa querencia también le condujo a la elaboración de una doctrina interpretativa más metódica que la transmitida por la tradición romanista.

Su punto de partida es el usual: la relación entre palabras y espíritu de la ley. Sostiene que el derecho no se reduce a lo que aparece escrito, porque en la misma escritura se contienen cosas no escritas que, sin embargo, son derecho. Todo derecho (ius) o toda ley (lex) constan de palabras y sentencia; mediante las primeras está escrita la ley, pero las segundas expresan lo que la ley quiere y siente. La sentencia se identifica con la mens legis, porque se dice que las palabras de la ley no han de entenderse sino para indicar lo que afirma el espíritu. Y el espíritu, aclara Doneau, no es lo que aparece escrito, sino lo que el legislador quiso, lo que su juicio aprobó y adoptó: es la causa de la ley y la que nos obliga ${ }^{139}$.

Si la literalidad de las palabras coincide con la sentencia, no cabe duda de que sólo es derecho lo que las palabras expresan, no por las palabras mismas, sino porque muestran lo querido y sentido por el autor. Si palabras y sentencia son discordantes, las primeras no serán derecho y no debemos ceñirnos a ellas: es la sentencia la que forma derecho. Como escribe Celso, conocer la ley no es quedarse en sus palabras, sino en su fuerza y potestad. Doneau precisa que este jurista romano quiso decir que no debemos limitarnos a memorizar y recitar las palabras de la ley, sino a captar su significado para saber lo que quiere la ley: sólo esto último será ley. Doneau remacha la idea: las palabras fueron creadas para entender la sentencia y e intención del hablante. Así empezaba Alciato su tratado, aunque Doneau no lo cita ahora; no sabemos si toma la idea del milanés o directamente de Quintiliano, que tampoco es mencionado en este punto. Lo importante es que Doneau utiliza esa idea para defender que la fuerza y potestad de las palabras está en el significado que exponga ese espíritu y sentencia. Las leyes no consisten en palabras sino en lo querido por su autor ${ }^{140}$.

${ }^{139}$ Doneau, Hughes, Commentariorum de iure civili libri viginti octo (Frankfurt, 1596), lib. I, cap. 13, pp. 30-31 : "Nam neque omne quod scriptum est, ius est, neque omne quod scriptum non est, ius non est. Proinde hinc quoque cognoscendum, quid in iis, quae scripta sunt, quaeque non scripta, pro iure habendum sit. Constat ius omne, seu lex omnis verbis, et sententia. [...] Verba sunt, quibus lex quaeque scripta est: sententia, quod lex ex verbis sentire et velle intelligitur. Idem mens legis: ut, cum dicimus verba legis captanda non esse, sed qua mente quid diceretur animadvertendum. [...] Non enim lex est quod scriptum est, sed quod legislator voluit, quod iudicio suo probavit et recepit, et hac solum de causa leges nos tenent".

${ }^{140}$ Ibíd., "Quocirca si verba cum sententia eadem erunt, sine dubio id ius erit, et solum ius, quod verba exprimunt: non tamen propter verba, sed quia auctor sensit et voluit. Quod si discrepabit sententia a verbis: quatenus id fiet, verba ius non erunt, eoque nec in his haerebimus: sententia ita ius erit, ut neque extra hanc sit verbis locus, et extra verba, quam longe patebit, hanc sequamur; quod generum explicatio docebit paulo post. Et hoc est, quod Celsus scripsit, scire leges non hoc esse verba earum tenere sed vim ac potestatem lex scire D. de leg. potestatem intelligit verborum et per haec legum: et hoc significant, scire leges non esse verba earum tenere memoria, ut recitare possimus, cum visum erit; sed eorum verborum significationem, qua fiat, ut sciamus, quid lex velit et sentiat, quo id sequamur: quoniam id solum vere est legi. Vis et potestas cuiusque rei Latinis dicitur effectus cuiusque rei, seu id, quam quaeque res potest, quodque efficit. Verba aiunt hoc valent, et ad hoc 
Reparemos en que este jurista utiliza el mismo vocabulario que sus compañeros de escuela desde el siglo XII, pero realiza un deslizamiento que podríamos calificar de "voluntarista". El espíritu de la ley aparece identificado con la intención del legislador de una manera más clara que en juristas anteriores (aunque estaba atisbada ya por Coras); ahora el espíritu parece identificarse con la intención del autor de la norma ${ }^{141}$.

De todas formas, la doctrina interpretativa que defiende también está llena de matices. Él explica que la relación entre palabras y sentencia puede a veces ser conflictiva: la segunda puede ser más estricta o más amplia que la primera ${ }^{142}$. Cuando es más estricta, hay diversos medios de solución: tener en cuenta otras partes de la misma ley, la ratio legis, la equidad, otras leyes relacionadas. La mención de la ratio legis es interesante, porque, según Doneau, a partir de ella se percibe de manera principal la voluntad y sentencia de la ley; la razón no es otra cosa que la voluntad de la ley, puesto que la ratio o causa es aquello que la ley se propuso y en función de lo cual se constituyó ${ }^{143}$.

Anacrónicamente, podemos decir que Doneau mezcla elementos subjetivos (la voluntad del legislador), con otros objetivos (la finalidad) al inquirir el significado de la ley, y esa actitud no era extravagante entre los romanistas. A pesar del hincapié que a veces hace en la intención del autor, la mención ahora de la equidad como criterio interpretativo muestra una tendencia más favorable hacia elementos más objetivizados. Según explica, la interpretación según equidad no implica obviar la ley, a condición de que esa interpretación esté basada en la equidad escrita. Podemos decir que para Doneau la ley acoge una justificación o causa (su equidad) que forma parte de ella y que debemos tener en cuenta para entenderla cabalmente. La referencia a la equidad no implica el uso de una instancia moral ajena al derecho, sino preguntar a la razón misma que otorga sentido a la ley ${ }^{144}$.

Cuando la sentencia es más estricta que las palabras, Doneau enumera criterios que a veces coinciden con los anteriores: las otras partes de la ley, el argumento $a$ contrario, el argumento a partir de las consecuencias, la ratio legis, el argumento

sunt inventa, ut mens et sententia loquentis intelligatur. Proinde verborum vis et potestas in hac ipsa significatione est, eoque in sententia et mente legis quae verbis exprimitur. [...] Hoc igitur dicit in summa, scire leges non esse, verba earum tenere, sed sententiam et mentem: quoniam leges non consistant in verbis, sed in eo, quod auctori voluit, idque et ubique et solum nos teneat".

${ }^{141}$ GuZmán, A., Codificación, cit. (n. 4), p. 111., señala la tendencia de Doneau a identificar la ley con la voluntad del legislador. Kriechbaum, M., "Verba" und “mens”, cit. (n. 104), pp. 56 ss.también piensa que Doneau identifica la mens con la intención del legislador.

${ }^{142}$ Cfr. Doneau, H., cit. (n. 139), lib. I, cap. $13^{\circ}, 31$.

${ }^{143}$ Ibíd., lib. I, cap. $13^{\circ}$, p. 32: "Ex hac praecipue voluntas et sententia legis perspicitur. Quinimo ratio nihil est, nisi voluntas legis: siquidem ratio et causa legis est id, quod lex sibi propositum habuit, ut legem constitueret; id, propter quod lex lata est, et sine quo lata non esset; denique quod lex in iure constituendo consequi voluit".

${ }^{144}$ Ibíd., lib. I, cap. $13^{\circ}$, p. 33: "Deprehenditur et ex aequitate sententia legis angustior, seu minus voluisset lex, plus scripsisse, cum quod generaliter et indistincte scriptum est, quibusdam in causis eiusdem generis iniquum videtur. Quam ob causam quoties id contingit, eadem hinc interpretationis regula recepta est, quam in ratione legis, ut lex in iis causibus, in quibus iniqua videatur, aequitatis regula temperetur". 
a $_{\text {similis }}{ }^{145}$. La influencia de los lugares comunes típicos de los tratados de retórica y tópica jurídica es patente, pero no es debida sólo al humanismo del autor, sino sobre todo a que eran típicos de la jurisprudencia romanista. En este punto, Doneau adopta una vía más "objetivista" de la comprensión de la ley, porque escribe que la sentencia de la ley es lo que esta tenía en el punto de mira y lo que quiso conseguir ${ }^{146}$. Por eso lleva razón Gayo -piensa Doneau- cuando escribió que donde está presente la misma razón es consecuente estimar el asunto de la misma forma. Doneau defiende claramente la extensión de la ratio legis a casos similares, pero también muestra alguna cautela. Cuando la ratio legis es clara y está presente en varias situaciones, no sólo puede aplicarse a otros casos parecidos sin necesidad de confirmación por parte de la autoridad superior, sino que es obligatorio hacerlo. Pero si hay dudas acerca de la igualdad de razón entre el caso regulado y el que ha de recibir la extensio, es preciso confirmar esa interpretación mediante la autoridad pública para que se considere derecho, bien mediante la judicatura, bien mediante la decisión del gobernante ${ }^{147}$. De acuerdo con estas reflexiones, Doneau piensa que la ley tiene sentido en función de la situación problemática a la que está dirigida. Una idea típica de la mentalidad romanista tradicional.

Al lado de los problemas ocasionados por la discrepancia entre verba y mens, aparecen los ocasionados por la ambigüedad del texto legal ${ }^{148}$. Observemos que son las mismas cuestiones repetidas por tantos juristas y contenidas en el tratado de Federicis. Doneau expone una serie de criterios destinados a solventar esa falta de claridad. Cuando no es posible conocer la sentencia de la ley, porque es dudosa, debemos seguir lo dispuesto en sus palabras. Al fin y al cabo, usamos las palabras para mostrar la voluntad: no debemos presumir que alguien dijo algo que no pensaba (al menos como criterio interpretativo y de acuerdo con lo dispuesto en el derecho romano). Pero si las palabras son ambiguas, o las oraciones son oscuras, porque un mismo discurso contiene varias sentencias, el problema es diferente. Hay una regula iuris procedente del título final de los Digesta que debe ser tenida en cuenta inicialmente: cuando las frases son ambiguas, debemos mirar la sentencia de quien pronunció las palabras. Pero, aclara Doneau, precisamente esta

${ }^{145}$ Ibíd., lib. I, cap. $14^{\circ}$, pp. 37 ss.

${ }^{146}$ Ibíd., lib. I, cap. $14^{\circ}$, p. 39: "Ex ratione legis intelligitur sententia legis latior, quam verba, cum constitutum quid est certis in rebus, casibusve lege expressis, sed ratione manifesta legis, quae ad alios casus similes non pertineat. Nam et iam supra dixi rationem legis, ipsam esse sententiam legis, ipsum id, quod lex voluit consequi, et propter quod lex lata est. [...] Si in aliqua causa sententia eorum manifesta est, ea ad similia produci, ac secundum hoc in his ius dici debet".

${ }^{147}$ Ibíd., lib. I, cap. $14^{\circ}$, p. 40: "Ubi ratio nota est, et apparet in aliis casibus eamdem esse, hinc lex ad similes casus sine alia superiore confirmatione non tantum porrigitur, sed et porrigi debet. Hinc neque iurisdictione praetoris olim, neque nunc costitutione principis opus est. [...]. Et merito: sic enim fit, quod lex voluit, voluntas legis lex est. Ita fit, ut in hac productione sicut voluntas legis, sic lex maxime conservetur quod facile privati omnes non solum possunt, sed etiam debent, atque adeo iubentur. Sed obscurum est interdum: nam in casibus, qui similes dicuntur, eadem aut par ratio sit. Quod si fit, et aliis par videtur, aliis minus: poterit sententia legis ad eos casus porrigi, sed confirmari interpretationem auctoritate publica oportet, id est, aut iurisdictione et edicto, aut constitutione principis, ut pro iure habeantur".

${ }^{148}$ Ibíd., lib. I, cap. 15 , pp. 41 ss. 
es la dificultad que queremos solventar, pues a causa de la oscuridad no sabemos lo que se quiso expresar. Para solucionarlo, nos informa de que ha ordenado una serie de preceptos transmitidos por los juristas antiguos que se hallaban dispersos (parece que no tiene en mucha estima la labor realizada hasta entonces).

La ambigüedad puede ser de una palabra individual o de una oración completa; también surge incertidumbre desde la naturaleza del asunto acerca del que se establece el derecho. Cuando la ambigüedad está en las palabras, Doneau ofrece los siguientes medios para solucionarla, que habrán de aplicarse de manera jerárquicamente ordenada en la medida en que resulten sucesivamente insatisfactorios:

En primer lugar, no debemos apartarnos del significado de las palabras, es decir, de su propiedad, salvo la evidencia de que el legislador quiso otra cosa. Por tanto, si la palabra tiene un significado propio y otro impropio (recordemos que el problema lo plantea ahora la pluralidad de significados), hemos de elegir el propio, a menos que resulte claro que la ley quiso otra cosa.

Si ocurre esto último, y no podemos elegir entre la diversidad de significados literales, emplearemos seriadamente estos criterios: la atención a lo que antecede y sigue en la misma ley al texto ambiguo. Si lo anterior no sirve, hay que escoger el significado que carezca de defectos (tal y como leemos en los Digesta); el fundamento de este criterio es que la ley procede del consejo de los prudentes (nuevamente una regla romana); como puntualiza Doneau, la interpretación defectuosa es aquella que produce una ley vacía e inútil o la que resulta inconveniente para el asunto regulado ${ }^{149}$. Si todas las interpretaciones posibles son defectuosas, es preciso consultar a la costumbre y a leyes anteriores. Si falla este último medio, se utiliza la regla "in dubiis benigniora" (una regula iuris aplicable a diversos problemas jurídicos) que prescribe aceptar la interpretación más benigna, es decir, más humana.

Cuando la ambigüedad surge de la oración se utilizan estos mismos criterios. En cambio, la incertidumbre en la naturaleza de la cosa regulada se presenta más complicada. Ocurre en asuntos en los que el derecho es claro, pero los hechos son inciertos, por ser muy infrecuentes o porque su desenlace no sea previsible; en tales casos la solución es entender la ley adaptada a lo que sucede normalmente ${ }^{150}$.

En Doneau y en Coras, menos quizá en Hopper, podemos observar una inclinación hacia una relativa jerarquización de criterios interpretativos. Los dos autores franceses sí mencionan explícitamente cierto orden para emplear los criterios, pero su utilización es calibrada en función del resultado; si un criterio conduce a un resultado razonable, no será preciso recurrir a otro; ahora bien, esa argumentación exige una determinación previa de lo considerado razonable; para eso es necesario valorar las consecuencias de la interpretación para el problema enjuiciado, la ratio y la utilidad presentes tanto en el asunto, como en la normas,

${ }^{149}$ Ibíd., libh. I, cap. 15, p. 43: "Recte ex hoc colligi, quoniam lex est virorum prudentium consultum, L. 1 D. de legibus, quorum prudentiae non convenit vitiose quid scripsisse. Vitiosa est significatio et interpretatio, si ex ea efficitur lex supervacua et inutilis".

${ }^{150}$ Ibíd., lib. I, cap. $15^{\circ}$, pp. 43 ss. 
etc. Se trata de cuestiones que no pueden ser resueltas de una manera técnica, sino mediante la apreciación prudente de bienes, principios y necesidades ${ }^{151}$.

Recordemos también que Doneau se refiere en algún momento a la equidad, aunque como un criterio interpretativo más; ya he mencionado que esto era habitual entre los romanistas, pero ahora encontraremos algún tratado en el que adquiere un papel más destacado en el plano expositivo. A todos estos juristas les parecía que la aequitas servía -entre otras cosas- para flexibilizar la aplicación de la ley, y esa posición la relacionaba con la interacción entre letra y espíritu. Hermann Vulteius escribía que en el derecho lo justo y equitativo no se oponen, ya que podemos decir que el ius strictum surge desde las palabras de la ley, mientras que la equidad está en su sentido o intención. Según Vulteius, Celso se refería a esa relación cuando escribió que conocer la ley no es quedarse sólo en sus palabras, sino atender a su fuerza y potestad ${ }^{152}$. En esa misma época, el cardenal Alberto Bolognetti o Bolognetus, (1536-1585) trató extensamente el papel de la equidad en la interpretación del texto legal. Se ocupó de estos asuntos en un tratado bastante influido por Tomás de Aquino ${ }^{153}$. Bolognetus aunó la tradición aristotélica con las doctrinas romanistas. Estudió la extensión y restricción de las palabras de la ley para amoldarlas a su espíritu dentro de los supuestos en los que la generalidad de la ley es incapaz de acoger todas las peculiaridades de un problema, tal y como había explicado Aristóteles. Bolognetus no ofrece ningún procedimiento técnico para resolver estas cuestiones; al contrario, remite la solución a las apreciaciones prudenciales. Precisamente al ocuparse de la restricción del significado de las palabras cuando este se opone a la mens legis, advierte de las dificultades. Reconoce que no es fácil llevar a cabo la interpretación en este tipo de asuntos, porque este problema aparece en los hechos singulares e individuales y en ellos concurren

${ }^{151}$ Fell, A. London, Origins of Legislative Sovereignty and the Legislative State, I: Corasius and the Renaissance Systematization of Roman Law (Cambridge - Königstein, Athenäum - Gunn and Hain, 1983), pp. 265-266, sostiene que los tratados de Rogerio y de Federicis son asistemáticos y fragmentarios comparados con el tratamiento de ese mismo tema por Coras; este es más sistemático y además conecta la cuestión interpretativa directamente con la legislación algo que, según Fell, no habían hecho los medievales. Cfr.. Quizá este autor exagere algo el sistematismo de Coras; este jurista es más ordenado que los tratadistas anteriores, pero el modelo de razonamiento que ofrece no es substancialmente diferente al propuesto por los juristas bajomedievales. Lo cierto es que el incipiente sistematismo de los juristas humanistas es de carácter externo: organizan la materia del ius commune a partir de nociones generales, pero no adoptan un esquema de razonamiento deductivo. Véase al respecto: RodríguEz PuERTO, M., La Modernidad, cit. (n. 66), pp. 315 ss.

${ }^{152}$ VulteiUs, Hermann, In Institutiones iuris civilis a Iustiniano compositas Commentarius (Marburgo, 1600), lib. I, p. 8, com. 2. "Quae accuratius hoc inspiciendo, non male dici possit, ex verbis legis induci jus strictum; ex sensu autem sive mente legis aequitatem: quo respexisse puto Celsum Jurisconsultum, cum dixit, scire leges non esse verba earum tenere, sed vim ac potestatem".

${ }^{153}$ Bolognetus, Albertus, De lege, iure et aequitate disputationes (Wittenberg, 1594), cap. $29^{\circ}, 10$, pp. 564 ss; cap. $29^{\circ}$, 14, p. 568 . Un análisis más detallado de los planteamientos de Bolognetus sobre la determinación de la solución justa en Rodríguez PuerTo, M. J., La Modernidad, cit. (n. 66), pp. 398 ss. Es interesante que sólo en la segunda mitad del siglo XVI los civilistas comiencen a hacerse eco de la obra tomista. Probablemente por influjo de los teólogos de la Escuela de Salamanca: Domingo de Soto aparece citado en esta obra de Bolognetus. En cualquier caso todos compartían un "espíritu común”. 
muchas cosas que hacen variar la interpretación de muchos modos; como son cuestiones que no pueden comprenderse en las leyes, tampoco es posible para nosotros establecer reglas ciertas que solucionen la cuestión ${ }^{154}$. No obstante, admite dos principios para llevar a cabo la restricción del significado. Según el primero, es imprescindible excluir cualquier solución interpretativa que lleve a resultado absurdos (por ejemplo, cuando la decisión interpretativa es opuesta a lo dispuesto en otra ley); Bolognetus considera que el resultado absurdo contraviene la razón natural. Según el segundo, ha de quedar claro que la razón que tuvo en cuenta el legislador no está presente en el caso enjuiciado ${ }^{155}$. Como vemos, ambos principios requieren una labor valorativa irreductible a las técnicas prefijadas.

Por otra parte, Bolognetus menciona tres criterios para conocer el espíritu de la ley: lo que precede o sigue a al texto interpretado; otras leyes y costumbre; el derecho natural. En estas instancias se encuentran exigencias de equidad que sirven para solucionar la cuestión ${ }^{156}$. Bolognetus afirma expresamente que esos tres medios entran en acción sucesivamente y en ese orden en la medida en que no sean capaces de elucidar el espíritu de la ley ${ }^{157}$. Sin embargo, estos criterios están lejos de solucionar asépticamente la cuestión, porque suponen la intervención de apreciaciones valorativas.

Una advertencia de Bolognetus resulta interesante. Confiesa que hay cierta disparidad a la hora de denominar esta tarea; algunos hablan de emendatio o directio, aunque él prefiere llamarla correcta exposición de la ley. Precisa que no es abrogatio, ni dispensa ni corrección de la ley ${ }^{158}$. La advertencia de Bolognetus estaba justificada, porque había quienes confundían esas actividades. Por ejemplo, ya en el siglo XV Juan de Gerson consideraba que las leyes humanas se redactan siempre de manera general, de manera que es necesario admitir excepciones en los casos particulares que el legislador no ha podido tener en cuenta. Gerson llama exceptio a esta necesidad y afirma que es denominada de diversas formas: es la epiqueya de Aristóteles, la interpretatio iuris de los legistas y la dispensatio de los canonistas, la buena fe de los políticos; a veces también es llamada aequitas ${ }^{159}$.

${ }^{154}$ Bolognetus, A., cit. (n. 153) cap. 34ํ, 25, pp. 649-650: “[...] videndum est, quidnam sit exquo possimus cognoscere, quando verba legis generalia ex aequo et bono coangustari possint. Non satis commode potest hoc ex omni parte explicari, cum in singularibus atque individuis factorum speciebus positum sit, multaque saepe concurrant, quae multis modis interpretationem variare solent. Quae omnia sicut lege comprehendi non possunt, ut post Aristot. tradit Iul. in lex non possunt, ff, de l. ita neque a nobis possunt certis regulis definiri".

${ }^{155}$ Ibíd., cap. $34^{\circ}, 22-30$, pp. 649-652.

${ }^{156}$ Ibíd., cap. $30^{\circ}, 1$, p. 574 .

${ }^{157}$ Ibíd., cap. $30^{\circ}, 7$, p. 577.

${ }^{158}$ Ibíd., cap. $30^{\circ}, 1$, p. 574 , cap. $32^{\circ}, 22$, p. 604.

${ }^{159}$ Gerson, Jean, Tractatus de Potestate ecclesiastica et de origine iuris et legum, consideratio 10 , en Opera omnia (Amberes, 1703), I, col. 241: "Leges humanae quae feruntur generaliter possunt et debent exceptionem recipere, dum deficit ratio Legis; quando videlicet Legislator, si adesset, vel alius prudens interrogatus exciperet a generali Constitutione casum particularem, qui taliter aut taliter occurreret. Haec autem exceptio multipliciter nominatur; quandoque epikeia sicut ab Aristotele; quandoque Juris interpretatio, sicut a Legistis; quandoque dispensatio, sicut a Canonistis; quandoque bona fides, sicut a Politicis, dicentibus bonam fidem esse, ubi non simulatur unum, et aliud agitur; quandoque dicitur aequitas, sicut ait Profeta Domino". 
Es interesante que Gerson agrupe todos estos conceptos diferentes. La tendencia imperativista de Gerson, no muy afín a las consideraciones prudenciales de los juristas, puede de ser la causa de su planteamiento. La ley es un mandato que se aplica o se inaplica, no es un precepto razonable que puede modularse según las circunstancias. La aclaración de Bolognetus (que no cita nombres), indica que la época mostraba ya otras tendencias más normativistas. Un contemporáneo de Bolognetus, el jurista y canónigo Fernando Vázquez de Menchaca (1512-1577), defendió un acercamiento a lo jurídico basado en la libertad natural individual que preludia el iusnaturalismo moderno. Además, adoptó posiciones voluntaristas para la moral, algo poco habitual entre los civilistas ${ }^{160}$. Al emplear los criterios interpretativos sigue fiel a la tradición romanista, al resaltar la preponderancia de la mens o sensus legis sobre la letra ${ }^{161}$. Vázquez de Menchaca escribe que el juez puede apartarse de las palabras de la ley para conseguir un resultado razonable; en los problemas interpretativos, cuando hay conflicto entre la significatio verbis y la mens legis, prevalece la segunda. Sin embargo, en alguna ocasión añade que en esos casos tiene lugar más bien una dispensatio que requiere la presencia de una justa causa ${ }^{162}$. Parece -es cuestión da matices- que en este punto identifica la ley con la textualidad y no acepta una modulación del significado en función de la finalidad: lo que ocurre tiene lugar es un cambio de significado a partir de una causa nueva.

\section{EL NACIMIENTO DE UN VERDADERO MÉTODO INTERPRETATIVO}

A lo largo del siglo XVI algunos teólogos escolásticos mantuvieron las doctrinas tomistas acerca de la justicia, lo que incluía la interpretación de la ley. Domingo de Soto se preguntaba si el súbdito puede actuar contra las palabras de la ley. Aunque parezca ilícito, cabe ese comportamiento si se dan ciertas circunstancias. Es preciso tener en cuenta que el discurso debe servir a las cosas y no al revés; en consecuencia, lo prudente es atender a la causa establecida por el legislador más que a la literalidad de sus palabras. Por otra parte, el uso del sentido literal de la ley para burlar su espíritu es una praevaricatio legis ${ }^{163}$.

Soto mantiene que la obediencia a la mens legis y no a los verba es la tarea de la epiqueya, que, no obstante, está sometida a limitaciones; él parece verla como algo excepcional y no como una modulación habitual de la ley según las circunstancias del caso. El motivo su preocupación por salvaguardar la posición de la ley. Sólo

${ }^{160}$ Véase: CARPINTERo, Francisco, Del dereho natural medieval al derecho natural moderno: Fernando Vázquez de Menchaca (Salamanca, Servicio de Publicaciones de la Universidad de Salamanca, 1977).

${ }^{161}$ Los ejemplos son abundantes. Al redspecto, véase: VÁZQUeZ de MenchaCA, Fernando, Controversiarum illustrium aliarumque usu frequentium libri tres (Venecia, 1574), lib. I, cap. $8^{\circ}$, 43, p. 34 ; lib. I, cap. $43^{\circ}, 3-4$, p. 121 ; lib. I, cap. $46^{\circ}, 5$, p. 129 . Explícitamente indica que en estas cuestiones hay que estar primero a la mens; en segundo lugar a lo verosímil, y en último a las palabras (lib. I, cap. $30^{\circ}, 6$, p. 91 ).

${ }^{162}$ Vázquez de Menchaca, F., Controversiarum, cit. (n. 161), lib. I, cap. 25, 7, p. 74.

${ }^{163}$ Soto, Domingo de, De iustitia et iure libri decem (edición de V. Carro. Madrid, Instituto de Estudios Políticos, 1968), lib. I, q. 6ª a. $8^{\circ}$, pp. 71 ss. 
cuando la ley rectamente puesta en general sea contraria al derecho natural en algunos casos particulares es lícito apartarse de ella, ya que, según Modestino, no tiene sentido que lo introducido para la utilidad de los hombres sea interpretado de una manera más severa; además, si el legislador hubiera tenido presente ese caso, lo habría considerado de manera diferente a como lo escribió ${ }^{164}$.

La restricción de la pluralidad de criterios interpretativos es especialmente patente en Francisco Suárez, el teólogo más influyente de la Escolástica tardía. Suárez (que cita a juristas como Baldo, o de Federicis) diferencia la epiqueya de la interpretación; toda epiqueya es interpretación, pero no toda interpretación es epiqueya; ésta tiene como misión establecer que la ley es defectuosa en un caso particular. En cambio, la tarea de la interpretación propiamente dicha es explicar el sentido de la ley cuando sus palabras son ambiguas ${ }^{165}$. La solución de este problema es comprensible si tenemos en cuenta, explica Suárez, que la forma interna de la ley consta de una materia -las palabras- y de un espíritu, la mens legislatoris. Él no entiende esta noción al modo plural de los juristas, sino que la identifica claramente con la voluntad de legislador; la justificación es que todo acto moral depende de la intención de su autor, y la ley, consecuentemente, deriva de la intención del legislador. Está claro que Suárez no ve el derecho como una serie de reglas y principios portadores de unas causas y razones, relacionadas a su vez con problemas y necesidades sociales. Los romanistas sí y, por eso, la interpretación giraba alrededor de esas causas. En cambio, Suárez piensa que la ratio de la ley es una causa o forma extrínseca pero no intrínseca de la ley; esto quiere decir que la ley se constituye por la presencia de la voluntad de un legislador, no por la sola causa justificativa. Por tanto, la interpretación no puede ser otra cosa que la averiguación de la intención del autor. Ésta intención se presume expresada en las palabras de la ley; si estas son claras ese es el sentido de la ley; si no, hay que acudir a la mens legislatoris. Cuando el caso no está previsto en esa mens, aparece la epiqueya que emplea la intención presunta del legislador ${ }^{166}$.

Al adoptar esta postura, Suárez no rompía abiertamente con la tradición romanista, porque estos juristas también tenían en cuenta las palabras y el espíritu de la ley, y estaban preocupados por la fidelidad a las leyes. Sin embargo, Suárez introdujo mayor rigidez de planteamientos: la ley es producto de la voluntad y la interpretación consiste en el hallazgo de la voluntad del legislador, que deviene así tanto medio como meta de la labor interpretativa ${ }^{167}$. Esta noción de la inter-

${ }^{164}$ Ibíd., p. 238.

${ }^{165}$ SuÁreZ, Francisco, Tractatus De legibus ac Deo legislatore (ed. bilingüe de J. R. Eguillor. Madrid, Instituto de Estudios Políticos, 1967-1968), lib. II, cap. 16º 4, p. 174.

${ }^{166}$ Ibíd., lib. III, cap. $20^{\circ}, 1,2,7$, pp. 282 ss.

${ }^{167}$ Carpintero, F., Justicia y ley natural, cit. (n. 29), pp. 327 ss. destaca la importancia del imperativismo jurídico de Suárez. Es preciso advertir que ese imperativismo queda rebajado por el fuerte objetivismo ético de estos escolásticos basado en la naturaleza inmutable de las cosas. La voluntad legisladora no puede ser omnímoda. Pero a la hora de aplicar las normas es preciso atender principalmente a esa voluntad que, previamente, ha acogido y respetado las exigencias del derecho natural. 
pretación tendrá gran éxito en los siglos posteriores ${ }^{168}$. No era una mera cuestión metodológica, porque la época era favorable a nuevas orientaciones políticas.

No es casual que autores (por otra parte diferentes) como Doneau y Suárez identificaran primariamente el derecho con la legislación y al mismo tiempo tendieran hacia cierta jerarquización de criterios interpretativos, a partir de la intención del legislador, aunque en el caso de Doneau, esa jerarquía estuviera matizada por la exigencia de racionalidad del resultado, que abría la tarea interpretativa a consideraciones más fronéticas.

Lo cierto es que a partir del siglo XVI es perceptible una tendencia de los gobernantes a intentar controlar la producción y la interpretación del derecho, aunque al mismo tiempo un conjunto de causas (el carácter estamental de la sociedad, la relevancia práctica del Derecho común, etc.) obstruyeran ese propósito ${ }^{169}$. Por otra parte, la práctica la interpretación siguió evolucionando a partir de los carriles romanistas, alrededor de la letra y el espíritu de las leyes. Desde luego, la intención del legislador ocupó una posición dominante y desplazó la consideración compleja y plural que tenían los romanistas, al hilo del amor por la simplicidad difundida en la mentalidad filosófica y científica a partir del siglo XVII. Pero también es preciso reconocer que la intención del legislador era identificada a veces con la propia de un legislador racional y que, incluso entre las corrientes más críticas con la tradición (como es Iusnaturalismo moderno) no llegó a instaurarse un método interpretativo completamente cerrado ${ }^{170}$.

\section{CONCLUSIÓN}

Aunque la práctica forense de la sociedad jurisdiccional, influida en buena medida por el ius commune, hubiera derivado en el casuismo caótico, las teoriza-

${ }^{168}$ Jan SCHroder y Alejandro GuZMán destacan la posición innovadora de Suárez al dar primacía a la intención del legislador como criterio interpretativo. Véanse, respectivamente: Recht als Wissenschaft, cit. (n. 32), p. 75 ss. y Codificación, cit. (n. 4), pp. 114 ss.

${ }^{169}$ Véanse: Mohnhaupt, Heinz, "Potestas legislatoria" und Gesetzesbegriff im Ancien Régime, en Ius Commune, 4 (Frankfurt a.M., 1972), passim; IMMEL, Gerhard, Typologie der Gesetzgebung der Privaterechts und Prozessrechts, en CoING, Helmut (editor), Handbuch der Quellen und Literatur der neueren europäischen Privatrechtsgeschichte (München, Beck, 1976), II, pp. 90 ss. Véase también los estudios referidos a distintos países europeos contenidos en: DöLEMEYER, Barbara - KLIPPEL, Diethelm, Gesetz und Gesetzgebung im Europa der Frühen Neuzeit (Berlín, Duncker \& Humblot, 1998). GuZMán, A., Codificación, cit. (n. 4), pp. 96 ss., señala que, a pesar de sus aspiraciones legislativas tendencialmente monopolizadoras, las monarquías absolutas no pretendieron crear un nuevo derecho, sino corregir e unificar el existente.

${ }^{170}$ Véase: Schröder, J., Recht als Wissenschaft, cit. (n. 32), 2a parte, pp. 97 ss.; ScHolz, Oliver, "Ius", "Hermeneutica iuris" und "Hermeneutica generalis". Verbindungen zwischen allgemeiner Hermeneutik und Methodenlehre des Rechts im 17. und 18. Jahrhundert, en SCHRÖDER, Jan (editor), Entwicklung der Methodenlehre in Rechtswissenschaft und Philosophie von 16. bis zum 18. Jarhhundert. (Stuttgart, Franz Steiner, 1998), pp. 86 ss. Scholz resalta la influencia posterior (hasta el siglo XIX) de los tratados elaborados por los romanistas sobre todo en la fase humanista. GuZmán, A., Codificación, cit. (n. 4), p. 106, revela que las codificaciones modernas se empeñaron el limitar la labor hermenéutica del ius commune, pero tuvieron que hacerlo empleando los conceptos que ese ius commune había desarrollado. 
ciones de muchos juristas romanistas muestran parecidos llamativos con reflexiones metodológicas actuales. Como sostiene Víctor Tau Anzoátegui, los romanistas primaron la finalidad de la norma sobre la literalidad porque así el casuismo se veía favorecido ${ }^{171}$, pero lo hicieron también al ser conscientes de la complejidad del significado en el derecho y la conciencia de esa realidad es independiente de la pertenencia a una sociedad jurisdiccional que exigiera una jurisprudencia casuista. Estos juristas comprendieron bien la tensión entre la adhesión a la norma y la apertura de su significado a las particularidades cambiantes de la cotidianidad. Ian MacLean destaca la continuidad entre bartolistas y humanistas en el problema de la interpretación: todos estos juristas partían de la existencia de una realidad extralingüística y entendían que las normas debían interpretarse en referencia a esa realidad $^{172}$. Aunque MacLean no la extraiga, pienso que de esa descripción de la actitud epistemológica de los romanistas se deriva una explicación de su noción de derecho. Para ellos, la presencia de esa realidad, demandante de soluciones, hacía que la interpretación se desplegara en esa constelación de causas, bienes, criterios y argumentos. Pendientes de esa complejidad presente en la red de interrelaciones sociales, estos romanistas no podían ceñir el derecho a un texto cerrado por una voluntad ordenadora, sino que lo abrían a las exigencias múltiples del tráfico social; desde este punto de vista una jerarquización metódica previa a la percepción del problema enjuiciado resultaba inviable ${ }^{173}$. Y aunque algunos romanistas influidos por el Humanismo muestren una tendencia hacia cierta jerarquía interpretativa, como indicaba antes los criterios empleados son los mismos que los juristas an-

${ }^{171}$ TAU, V., cit. (n. 7), p. 517.

${ }^{172}$ MacLean, I., cit. (n. 32), p. 209. La misma opinión sobre las doctrinas del Humanismo (sin mención específica del derecho) en GonZÁlez, G., cit. (n. 15), pp. 342 ss. Apel, Karl-Otto, Die Idee der Sprache in der Tradition des Humanismus von Dante bis Vico (Bonn, Bouvier, 1963), pp. 273 ss., ha escrito que la doctrina humanista sobre el lenguaje fue de tipo retórico y concibió la realidad lingüística como una comunidad en la que se expresa la intersubjetividad de la razón; no obstante, precisa Apel, estos humanistas no acabaron de afirmar que el lenguaje fuera el horizonte donante de todo sentido, ni se desprendieron de la función representantiva del lenguaje (que él considera propio de la línea aristotélico-ockhamista) en la que este es signo de cosas exteriores. Por supuesto, los juristas romanistas, tanto medievales como humanistas, no otorgaron ese papel donante de sentido al lenguaje, porque eran ajenos a los presupuestos de cierta Hermenéutica del siglo XX que estructura la realidad en el lenguaje, y partían de la incuestionada existencia de cosas, situaciones, bienes y necesidades reales que marcaban las líneas a la juridicidad. Un análisis detallado de esta ontología jurídica, que incluye consideraciones sobre un derecho natural de diversas vertientes, se halla en los estudios de CARPINTERO, Francisco, Nuestros prejuicios sobre el llamado derecho natural, en Persona y Derecho, 27 (Pamplona, 1992); EL MISMO, Historia y justicia según los juristas de formación prudencial, en Anuario de Filosofia del Derecho, 9 (Madrid, 1992); El MISMO, Historia breve del derecho natural (Madrid, Colex, 2000), pp. 13 ss., 95 ss.

${ }^{173}$ Sí hay que reconocer que los romanistas premodernos se olvidaron un tanto de la certeza de la ley y del sujeto que necesitaba esa certeza, y esa puede ser una causa de la despreocupación por normas rígidas en ámbitos como el derecho penal típica de la sociedad estamental. El asunto es complejo, porque debemos recordar que los romanistas propugnaron la interpretación estricta de esas normas. 
teriores y, al final, hacen giran la clave interpretativa alrededor de la racionalidad de los resultados y no del empleo de una técnica predeterminada ${ }^{174}$.

Tal vez exageraron la diversidad de criterios y puntos de vista desde los que extraer el significado de la ley, pero su prolijidad no es tan diferente de la que se encuentra en tratados más recientes sobre metodología jurídica que no están redactados por defensores de la sociedad jurisdiccional ${ }^{175}$. Muchos juristas actuales reconocen, al igual que sus antecesores romanistas, la imposibilidad de ceñir por completo la interpretación mediante un método ajeno a las consideraciones prudentes y circunstanciadas.

\section{BiBLIOGRAFÍA}

Ajello, Raffaele, Arcana Juris. Diritto e politica nel Settecento Italiano (Napoli, Jovene, 1976).

Alciato, Andrea, De verborum significatione, en Opera omnia in quattuor tomos legitime digesta (Frankfurt, 1617).

Alonso, María Paz, El proceso penal en Castilla (siglos XIII-XVIII). (Salamanca, Ediciones Universidad de Salamanca, 1982).

Apel, Karl-Otto, Die Idee der Sprache in der Tradition des Humanismus von Dante bis Vico (Bonn, Bouvier, 1963).

Aristóteles, Ética a Nicómaco (trad. de J. Pallí. Madrid, Gredos, 1993).

Aristóteles, Retórica (trad. de Q. Racionero, Madrid, Gredos, 1990).

Bentham, Jeremy, OfLaws in General (edición de H.L.A. Hart, University of London - The Athlone Press, 1970).

Bolognetus, Albertus, De lege, iure et aequitate disputationes (Wittenberg, 1594).

Budé, Guillaume, Annottationes ad Pandectas.

CAEPOLla, Bartolomeo, In titulum de verborum et rerum significatione doctissima commentaria. (Lyon, 1551).

CANARIS, Claus-Wilhelm, Das Rangverhältnis der klassischen Auslegungskriterien, demonstriert an Standardproblem aus dem Zivilrecht, en BEUTHIEN, Volker y otros (editores), Festschrift für Dieter Medicus. Zum 70. Geburtstag (Colonia, Carl Heymanns, 1999).

Carpintero, Francisco, "Mos italicus", "mos Gallicus" y el Humanismo racionalista, en Ius Commune, 10 (Frankfurt a.M., 1978).

Carpintero, Francisco, Del derecho natural medieval al derecho natural moderno:

${ }^{174}$ SCRÖDER, J. Recht als Wissenschaft, cit. (n. 32), p. 74, ha escrito que el ius commune adoptó una postura "racionalista" ante la interpretación.

${ }^{175}$ Un ejemplo interesante es la recopilación de estudios sobre la interpretación de las leyes coordinada por Neil MacCormick y Robert Summers y que abarca diversos paises para mostrar la variedad de criterios empleados. Finalmente los recopiladores admiten que no es posible establecer una jerarquía de métodos interpretativos. Véase:. Interpreting Statutes. A Comparative Study (Aldershot/Vermont, Darmouth, 1991), per totum. La abundantes variaciones que presentan las interpretaciones objetiva y subjetiva, por ejemplo, aparecen en: MEUNICKEN, Axel, Das Ziel der Gesetzesauslegung. Eine Untersuchung zur subjektiven und objektiven Auslegungstheorie (Bad Homburg - Berlin - Zurich, Gehlen, 1970), per totum. Este autor considera imposible determinar a priori el mejor tipo de interpretación. 
Fernando Vázquez de Menchaca (Salamanca, Servicio de Publicaciones de la Universidad de Salamanca, 1977).

Carpintero, Francisco, En torno al método de los juristas medievales, en Anuario de Historia del Derecho Español, 52 (Madrid 1982).

Carpintero, Francisco, Historia breve del derecho natural (Madrid, Colex, 2000).

Carpintero, Francisco, Historia y justicia según los juristas de formación prudencial, en Anuario de Filosofía del Derecho, 9 (Madrid, 1992),

Carpintero, Francisco, Justicia y ley natural: Tomás de Aquino y los otros Escolásticos (Madrid, Servicio de Publicaciones de la Facultad de Derecho de la Universidad Complutense, 2004).

CarPintero, Francisco, Nuestros prejuicios sobre el llamado derecho natural, en Persona y Derecho, 27 (Pamplona, 1992).

Carpintero, Francisco, Tomás de Aquino ante la ley natural, Dikaiosyne, 8 (Mérida, Venezuela, 2002).

Clavero, Bartolomé, La disputa del método en las postrimerías de una sociedad (17891808), en Anuario de Historia del Derecho Español, 48 (Madrid, 1978).

Collantes de TerÁn, María José, La administración de justicia en la época constitucional (Cuenca, Alfonsípolis, 2006).

CorAs, Jean, De iuris arte liber, en Tractatus universi iuris (Venecia, 1584), I.

CORTESE, Ennio, La norma giuridica (Milano, Giuffrè, 1962), I.

Costa, Pietro, Semantica del potere politico nella pubblicistica medievale (1100-1433) (Milano, Giuffrè, 1969).

Dölemeyer, Barbara - KLippel, Diethelm, Gesetz und Gesetzgebung im Europa der Frühen Neuzeit (Berlín, Duncker \& Humblot, 1998).

Doneau, Hughes, Commentariorum de iure civili libri viginti octo (Frankfurt, 1596).

FederICIS, Stephanus de, De interpretatione legum, en Tractatus universi iuris (Venecia, 1584), I,

FELl, London, Origins of Legislative Sovereignty and the Legislative State, I: Corasius and the Renaissance Systematization of Roman Law (Cambridge - Königstein, Athenäum - Gunn and Hain, 1983).

Garriga, Carlos, Orden jurídico y poder político en el Antiguo Régimen, en Istor. Revista de Historia Internacional, 16 (México D.F., 2004).

Gentili, Alberico, De iuris interpretibus libri sex (edición de G. Astuti, Turín, Instituto Jurídico de la Universidad, 1937).

GERSON, Jean, Tractatus de Potestate ecclesiastica et de origine iuris et legum, consideratio 10, en Opera omnia (Amberes, 1703), I.

GonzÁlez Alonso, Benjamín, Jueces, justicia y arbitrio judicial. (Algunas reflexiones sobre la posición de los jueces ante el Derecho en la Castilla moderna), en Vivir el Siglo de Oro. Poder, Cultura e Historia en la época moderna. (Salamanca, Ediciones Universidad de Salamanca, 2003).

GonZÁlEz, Gabriel, Dialéctica escolástica y lógica humanista de la Edad Media al Renacimiento (Salamanca, Ediciones Universidad de Salamanca, 1987).

Grondin, Jean, Introducción a la Hermenéutica filosófica (trad. de A. Ackermann. Barcelona, Herder, 1999).

GuZMÁn, Alejandro, Codificación del Derecho civile interpretación de las leyes (Madrid, Iustel, 2011).

GuZMÁn, Alejandro, Ratio scripta (Frankfurt a.M., Vittorio Klostermann, 1981). 
Hopper, Joachim, Seduardus sive De vera iurisprudentia ad regem libri XII (Amberes, 1590).

Horn, Norbert, Aequitas in den Lehren des Baldus (Colonia - Graz, Böhlau, 1968).

Hotman, François, Iurisconsulti sive de optimo genere iuris interpretandi liber, en Cynosura Iuris (Spira, 1588).

Immes, Gerhard, Typologie der Gesetzgebung der Privaterechts und Prozessrechts, en CoING, Helmut (editor), Handbuch der Quellen und Literatur der neueren europäischen Privatrechtsgeschichte (München, Beck, 1976), II.

Kriechbaum, M., Verba und mens in den Interpretationslehren des Humanismus, en SCHRÖDER, Jan (editor), Theorie der Interpretation von Humanimus bis zur Romantik. Rechtswissenschaft, Philosophie, Theologie (Stuttgart, Steiner, 2001).

Lange, Hermann - Kriechbaum, Maximiliane, Römisches Recht im Mittelalter, II: Die Kommentatoren (München, Beck, 2007).

Le Douaren, François, In primam partem Pandectarum, en Opera omnia (Lyon, 1554).

Lombardi, Luigi, Saggio sul Diritto giurisprudenziale (Milano, Giuffrè, 1975).

MacCormick, Neil - Summers, Robert, Interpreting Statutes. A Comparative Study (Aldershot/Vermont, Darmouth, 1991).

MaCLEAN, Ian, Interpretation and Meaning in the Renaissance. The Case of Law (Cambridge University Press, 1992).

Melanchthon, Philip, Oratio in promotione cuiusdam iurisconsulti, habita a Doctore Sebaldo Munstero Res non iudicandas secundum arbitrium iudicis sed secundum scriptum ius (1532), en KISCH, Guido, Melanchthons Rechts-und Soziallehre (Berlín, De Gruyter, 1967).

Melanchthon, Philip, Oratio publice habita Vuittenbergae in promotione Doctores iuris de scripto iure et dignitate veterum interpretium iuris (1539), en $\mathrm{KISCH}$, Guido, Melanchthons Rechts- und Soziallehre (Berlín, De Gruyter, 1967).

Meunicken, Axel, Das Ziel der Gesetzesauslegung. Eine Untersuchung zur subjektiven und objektiven Auslegungstheorie (Bad Homburg - Berlin - Zurich, Gehlen, 1970).

Mohnhaupt, Heinz, "Potestas legislatoria" und Gesetzesbegriff im Ancien Régime, en Ius Commune, 4 (Frankfurt a.M., 1972).

Ogorek, Regina, Richterkönig oder Subsumtionautomat? Zur Justiztheorie im 19. Jahrhundert (Frankfurt a. M., Klostermann, 1986).

Ortego, Pedro, Notas sobre el arbitrio judicial usque ad mortem en el Antiguo Régimen, en Cuadernos de Historia de Derecho, 11 (Madrid, 2004).

Отте, Gerhard, Dialektik und Jurisprudenz (Frankfurt a.M., Vittorio Klostermann, 1971).

Piano Mortari, Vincenzo, Il problema dell" interpretatio iuris" nei Commentatori, en Annali di Storia del Diritto, 2 (Milano, 1958).

PIANO-MorTARI, Vincenzo, Ricerche sulla teoria dell'interpretazione del diritto nel secolo XVI, I: La premesse (Milano, Giuffrè 1956).

Quintiliano, Marco Fabio, De institutione oratoria.

Rodríguez Puerto, Manuel Jesús, La modernidad discutida (Cádiz, Servicio de Publicaciones de la Universidad de Cádiz, 1999).

Rodríguez Puerto, Manuel Jesús, Tópica y humanismo jurídico, en Anuario de Filosofía del Derecho, 18 (Madrid, 2001).

RogerIo, Constantino, De iuris interpretatione, en Tractatus universi iuris (Venecia, 1584), I. 
Scholz, Oliver, "Ius", "Hermeneutica iuris" und "Hermeneutica generalis". Verbindungen zwischen allgemeiner Hermeneutik und Methodenlehre des Rechts im 17. und 18. Jahrhundert, en SCHRÖDER, Jan (editor), Entwicklung der Methodenlehre in Rechtswissenschaft und Philosophie von 16. bis zum 18. Jarhhundert. (Stuttgart, Franz Steiner, 1998).

Sснотт, Clausdieter, "Interpretatio cessat in claris”. Auslegungsfähigkeit und Auslegungsbedürftigkeit in der juristischen Hermeneutik, en SCHRÖDER, Jan (editor), Theorie der Interpretation von Humanimus bis zur Romantik. Rechtswissenschaft, Philosophie, Theologie (Stuttgart, Steiner, 2001).

SCHRÖDER, Jan, Recht als Wissenschaft (München, Beck, 2001).

Smith, Adam, Lectures on Jurisprudence (edición de R.L. Meek, D.D. Raphaey P.G. Stein. Oxford, Clarendon Press, 1978).

Soto, Domingo de, De iustitia et iure libri decem (edición de V. Carro. Madrid, Instituto de Estudios Políticos, 1968).

SuÁreZ, Francisco, Tractatus De legibus ac Deo legislatore (ed. bilingüe de J. R. Eguillor. Madrid, Instituto de Estudios Políticos, 1967-1968).

Tau AnzoÁtegui, Víctor, Casuismo y sistema (Buenos Aires, Instituto de Investigaciones de Historia del Derecho, 1992).

Thoma Aquinat., Comentario al libro de Aristóteles sobre la interpretación (trad. de M. Skarica, Pamplona, EUNSA, 1999).

Thoma Aquinat., De regno ad regem Cypri.

Thoma Aquinat., Summa Theologiae (citada según la edición digital de la obra tomista por Enrique Alarcón en http://www.corpusthomisticum.org).

Vallejo, Jesús, Ruda equidad y ley consumada. Concepción de la potestad normativa (1250-1350) (Madrid, Centro de Estudios Constitucionales, 1992).

VÁzQuez de Menchaca, Fernando, Controversiarum illustrium aliarumque usu frequentium libri tres (Venecia, 1574).

VIVES, Luis, Las disciplinas, en Obras Completas (trad. de L. Riber, Madrid, Aguilar, 1947. Reprint de la Generalitat Valenciana, 1992).

VulteIUs, Hermann, In Institutiones iuris civilis a Iustiniano compositas Commentarius (Marburgo, 1600). 
